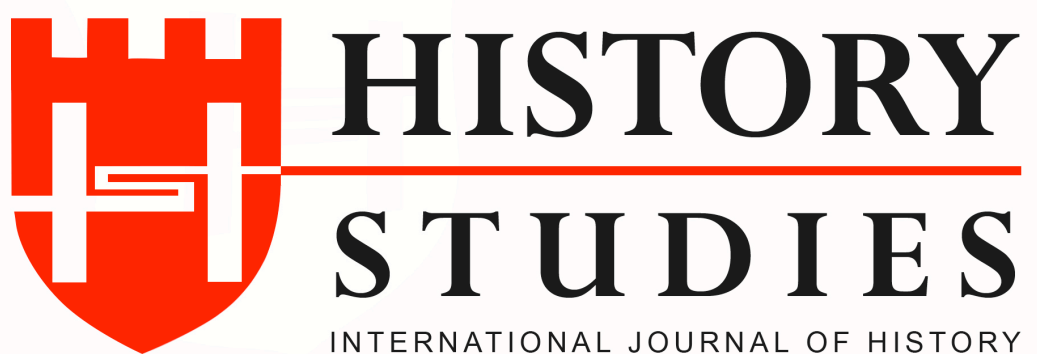

ISSN: 13094173 (Online) 1309 - 4688 (Print)

Volume 11 Issue 3, June 2019

DOI Number: 10.9737/hist.2019.743

Araştırma Makalesi

Makalenin Geliş Tarihi: 02.05.2019 Kabul Tarihi: 14.05.2019

Atıf Künyesi: Arda Baş, “Orgeneral Şahap Gürler ve Demokrat Parti Döneminde Siyasi Faaliyetleri”, History Studies, 11/3, Haziran 2019, s. 839-860.

\title{
Orgeneral Şahap Gürler ve Demokrat Parti Döneminde Siyasi Faaliyetleri
}

\author{
Gen. Şahap Gürler and Political Activities in the Democrat Party Era \\ Dr. Arda Baş
}

ORCID No: 0000-0003-4789-9220

Bolu Abant İzzet Baysal üniversitesi

\section{Özet}

II. Meşrutiyet'ten 27 Mayıs'a kadar devam eden süreçte asker ve sivil olarak kariyeriyle Şahap Gürler, Türkiye'de ordu-siyaset ilişkilerinin karmaşıklığına tipik bir örnektir. Demokrat Parti döneminde askeri kariyerinin en önemli görevlerini yerine getiren Gürler, aynı dönemde ani bir kararla emekliye sevk edilmiştir. Ordudan ayrılmasının ardından CHP saflarında aktif siyasete girmiş ve 27 Mayıs'a giden süreçte CHP ile ordu arasındaki önemli bağlantılardan biri olmuştur.

Bu çalışmada Demokrat Parti iktidarına yönelik bir darbe girişimi şüphesiyle ani bir şekilde emekliye sevk edilen Gürler'in asker ve sivil hayatındaki faaliyetleri incelenerek Türkiye'de ordu-siyaset ilişkilerinin daha iyi anlaşılmasına katkı sunulması amaçlanmıştır.

Anahtar Kelimeler: Şahap Gürler, Ordu-Siyaset İlişkileri, Cumhuriyet Halk Partisi, Demokrat Parti, 27 Mayıs 1960 Darbesi

\section{Abstract}

In the process from the Second Constitutional Era to the coup of 27 May, Şahap Gürler, with his career as a soldier and civilian, is a typical example of the complexity of relationship between military and politics in the Turkey. Gürler who fulfilled the most important duties of his military career during the Democratic Party was retired by a sudden decision in the same period. After leaving the army, he went into active politics in the ranks of the CHP and became one of the important links between the CHP and the army in the process leading to the coup of 27 May.

This study examines the activities of Gürler in his military and civilian life, who was retired on suspicion of a military coup attempt against Democrat-Party-Government by a sudden decision, and aims to contribute to understanding the relationship between military and politics in Turkey.

Key Words: Şahap Gürler, relationship between military and politics, Democrat Party, the military coup of 27 May 1960 
Giriş

1886 yılında Edirne'de doğan Şahap Gürler'in babası Osman Nuri Bey, annesi Seher Hanım'dır. Aile'nin tek çocuğu olan Gürler, Edirne'nin meşhur okullarından Karabulut mektebine gitmiştir. Babasından dolayı askerlik mesleğini tanımış ve sevmiştir. Bu nedenle askeri okula gitmiş üç yıl okumasının ardından babası onu askeri okuldan alarak Galatasaray Lisesi'nde okutmak istemiş̧ir. Ancak Gürler, asker olmak istediği için buna itiraz etmiştir. Galatasaray Lisesi'ne kaydolmadan İstanbul'dan Edirne'ye kaçmış ve Edirne'de askeri idadiye kaydolmuştur. İki yıl Edirne'de eğitim görmüş ardından Kuleli'ye gelerek buradan mezun olmuştur. Haliç’teki Topçu Mühendishanesinde aldığı iki yıllık eğitimi birincilikle bitirmiştir. Mezuniyetin ardından 1914'te asteğmen olarak Edirne'deki topçu alayına, ardından Çanakkale Cephesine gönderilmiştir. Çanakkale Cephesi'nden sonra Filistin Cephesi'ne gitmiş bu esnada Mondros Mütarekesi imzalanarak Osmanlı Devleti teslim olmuştur. Pek çok subay gibi ordunun terhis edilmesinin ardından İstanbul'a dönmüştür. İstanbul'da fazla kalmayarak dönem arkadaşı Fevzi Mengüç ile birlikte Yeni Camii önündeki bir eskiciden iki liraya aldıkları sivil elbiseler ile gizlice Anadolu'ya geçmişlerdir. Ankara Hükümeti tarafından önce üsteğmen rütbesi ile Genelkurmay Harekat Şubesi'nde görevlendirilmiştir. Milli Mücadele yıllarında kurmay stajını yaparak yüzbaşı olmuştur. Savaşın ardından Yıldız Askeri Akademisini iki yılda bitirmiştir. Ardından o dönemde adı Milli Emniyet Hizmeti Riyaseti olan Milli İstihbarat Teşkilatı'nda çalışmıştır. 1934 yılında yarbay rütbesi ile Konya'da görev yaptıktan sonra Burdur Topçu Alay Komutanlığı'na getirilmiştir. Burdur Jandarma Komutanı Albay Hüsnü Pekşen'in kızı Emel Hanım ile burada tanışmış ve evlenmiştir. Gürler, 1940 yılında general olmuş ve II. Dünya Savaşı yıllarında Türkiye'nin en kritik bölgelerinden biri olan Kars'ta görev yapmıştır. Eşi Emel Hanım ve o dönemde askerlik görevi için Kars'ta bulunan şair Behçet Kemal Çağlar'ın yardımı ile savaş boyunca bu kritik bölgede halkın moralini yüksek tutmak için yoğun bir şekilde çalışmışlar, piyesler sahnelemiş ve şiirler okumuşlardır. Gürler, yedi yıl doğuda görev yapmasının ardından 1946'da Çatalca'ya tayin edilmiş ve korgeneral olmuştur. ${ }^{1}$ Görev yaptığı sürece inisiyatif almaktan çekinmeyen bir komutandır. Adatepe adlı savaş gemisinde yapılacak tatbikata I. Ordu Komutanı adına korgeneral olarak katıldığında yapılan atışların başarısız olduğunu görmüş misafir olarak bu tatbikata katılmasına rağmen Genelkurmay Başkanlığı'na rapor yazarak gemicilerin savaşamayacak ölçüde yetersiz olduğunu belirtmiştir. ${ }^{2}$

Gürler'in görev yaptığı yıllarda Genelkurmay Başkanı Fevzi Çakmak, orduda modernizasyon taleplerine karşı çıkmış terfiler yetenekten ziyade kıdem esas alınarak gerçekleşmiştir. Bu dönemde ordunun üst kademelerinde modern savaş sanatı ile ilgili eğitim alan general kalabalık kadroya rağmen çok azdır. ${ }^{3}$ II. Dünya Savaşı ile birlikte hızla değişen savaş teknik ve teknolojisine uyum sağlamak Türkiye için hayati önem taşıyordu. Bu nedenle Demokrat Parti'nin (DP) muhalefette olduğu ve Türkiye'nin çok partili düzene geçmeye çalıştığ 1 yıllarda ordu da kamuflajına kadar topyekûn Amerikan modeline göre yeniden yapılanma içine girmiştir. ${ }^{4}$ Batılı askeri yetkililerle temaslar bu nedenle büyük önem taşıordu. ABD Ordu Bakanı Kenneth Royall, Genelkurmay Başkanı Thomas Rimbernu ve askeri heyet ile 17 Kasım 1948'de İstanbul'a geldiğinde onları karşılayan Orgeneral Nuri Yamut ve İstanbul

\footnotetext{
${ }^{1}$ Akis, 30 Haziran 1960, s.17-20., Milliyet, 9 Ekim 1966.

2 Taner Gün, “Atatürk'ün Donanma Gemileri ile Yaptığı Geziler”, Dokuz Eylül Üniversitesi, Atatürk İlkeleri ve İnkılap Tarihi Enstitüsü, İzmir 2007, s. 75. (Yayımlanmamış Yüksek Lisans Tezi)

${ }^{3}$ William Hale, Türkiye'de Ordu ve Siyaset: 1789'dan Günümüze (Çev: Ahmet Fethi), Hil Yayınları, İstanbul 1996, s.92.

4 Çetin Yetkin, Türkiye'de Askeri Darbeler ve Amerika, 27 Mayls, 12 Mart ve 12 Eylül'de ABD'nin Yeri, Ümit Yayınc1lık, Ankara 1995, s. 23-25. 
Komutanı (1. Ordu Komutan Vekili, 1949 Birinci Ordu Müfettişi) Korgeneral Gürler olmuştur. ${ }^{5}$ Gürler görevi gereği Cumhuriyet Halk Partisi (CHP) iktidarda iken ABD’li üst düzey askerlerle sürekli temas halinde olmayı sürdürmüştür. ${ }^{6}$

\section{Gürler'in Demokrat Parti Döneminde Asker Olarak Faaliyetleri}

DP 14 Mayıs 1950'de iktidara geldiğinde ordu içinde CHP yanlısı ve karşıtı çeşitli askeri gruplar mevcuttu. Özellikle 1946 seçimlerinden sonra ordu içinde bazı gruplar çeşitli müdahale planları hazırlamışlar ancak bunlar gerek yeterince güçlü olmadıkları gerekse İsmet İnönü'nün siyasi tansiyonu yükseltmeyen kontrollü tutumu nedeniyle harekete geçememişlerdir. Ordu içindeki CHP karşıtı askerler bir süredir ordunun rejim içinde ağırlığının kaybolduğunu düşündükleri için CHP'ye tepkiliydi. Onlar DP'nin iktidara gelmesini demokrasi zaferinden ziyade orduda yaratabileceği değişim nedeniyle heyecan ile karşılamışladır. Genç subaylar DP'nin iktidara gelmesiyle ordu üst kademesinde köklü bir değişiklik yaşanacağını ve alt kademe subayların bu süreçte yükselme imkânı yakalayacağını, ordunun hızla modernleșeceğini düşünüyorlardı. Zaten 1944'deki Türkçülük ve Turancılık Davasından sonra genç subaylar ile CHP iktidarı arasındaki ilişki ciddi anlamda sarsılmıştı. Bir diğer husus bazı subaylar CHP'nin 1945'ten sonra Atatürk ilkelerinden ayrıldığını görüşündeydiler. Şevki Kurtcebe, Cemal Tural gibi subayların kurdukları gizli yapılar ile 1950 yılına kadar gelindi. DP 1950'de iktidara geldiğinde kendisini destekleyen önemli bir subay grubu vardı. Hatta bunların bir kısmı seçimlerden önce Celal Bayar ile görüşme yaparak desteklerini açıkladı. Ordu içinde aynı günlerde İnönü ile temas halinde olan subaylarda bulunmaktaydı. ${ }^{7}$ Daha DP iktidara gelmeden önce ordu içinde siyasete müdahale isteği vardı. ${ }^{8}$

DP seçimlerin ardından iktidarı resmen devralmasına rağmen 27 yıllık CHP iktidarının sivil ve askeri bürokrasine hakim değildi. DP'liler ordunun iktidarı kendilerine devretmek konusunda isteksiz olduğunu düşünüyorlardı. Bu nedenle DP devlet mekanizmasına fiilen hakim olarak iktidarını sağlamlaştırmak istiyordu. DP hükümetinin güvenoyu aldığı günlerde 5 Haziran 1950'da bir albay Menderes'i ani bir şekilde ziyaret ederek, ordu içindeki İnönü taraftarı generallerin 8-9 Haziran gecesi bir darbe yapacağı ihbarında bulundu. ${ }^{9}$

Menderes ile Bayar bu gelişme üzerine bir araya geldi. Bu görüşme basına Milli Savunma Bakanlığı bütçesinde bir zaaf meydana getirmeden yapılabilecek tasarruf ile ilgili olarak 5-6 Haziran'da Bayar, Menderes, Milli Savunma Bakanı, Genelkurmay Başkanı ve kuvvet komutanlarının katıldığı üst düzey bir dizi toplantı yapıldığı şeklinde yansıd ${ }^{10}{ }^{10}$ İhbarın ardından ordundan 1181 asker tasfiye edilerek cumhuriyet tarihinde ordu içindeki en büyük değişikliklerden biri yapıldı. ${ }^{11} 6$ Haziran'da çıkan haberlere göre Genelkurmay Başkanı Orgeneral Abdurrahman Nafiz Gürman'ın yerine Orgeneral Nuri Yamut, İkinci Başkan İzzet Aksalur'un yerine Korgeneral Gürler tayin edilmiş, Org. Salih Omurtak, Kazım Orbay ve Hakk1 Akoğuz ise emekliye sevk edilmişti. Birinci Ordu Kumandanı Asım Tınaztepe, II. Ordu Kumandanı Muzaffer Tuğsavul, Üçüncü Ordu Kumandanı Mahmut Berköy, Askeri Şuraya

\footnotetext{
${ }^{5}$ Ayın Tarihi, Aralık 1948, http://ayintarihi.iletisim.gov.tr/turkce

${ }^{6}$ Ayın Tarihi, Mart 1949, http://ayintarihi.iletisim.gov.tr/turkce

7 Ümit Özdağ, Ordu-Siyaset İlişkisi: Atatürk-İnönü Dönemleri, Gündoğan Yayınları, Ankara 1991, s. 164-165., Yetkin, a.g.e., s. 23-25., Kurtuluş Kayal1, Ordu ve Siyaset 27 Mayıs-12 Mart, İletişim Yayınları, İstanbul 1994, s. 6061., O. Metin Öztürk, Ordu ve Politika, Gündoğan Yayınları, Ankara 2000, s.65.

${ }^{8}$ Yetkin, a.g.e., s. 23-25.

${ }^{9}$ Cem Eroğul, Demokrat Parti Tarihi ve İdeolojisi, İmge Yayınevi, Ankara 2003, s. 97-100., Özdağ, s. 84-87., Şevket Süreyya Aydemir, İkinci Adam, III. Cilt, Remzi Kitapevi, İstanbul 1968, s. 45-49.

${ }^{10}$ Akşam, 6 Haziran 1950.

${ }^{11}$ Ümit Özdă̆, Menderes Döneminde Ordu-Siyaset İlişkiler ve 27 Mayıs İhtilali, Boyut Yayıncılık, İstanbul 1997, s. 84-87.
} 
tayin oldu. Deniz Kuvvetleri Kumandanı Mehmet Ali Ülgen ile Hava Kuvvetleri Kumandanı Zeki Doğan da merkeze alınarak pasif görevlere getirilmişlerdi. Üstelik 15 general ve 150 albay için emeklilik kararı verildi. Menderes, bu ani değişiklikle hukuki olarak elde ettiği iktidara fiili olarak da sahip oldu. ${ }^{12} \mathrm{Bu}$ hareket esnasında DP ordudan önemli ölçüde destek aldı. Ancak destek verenlerin en önemli beklentisi yani ordunun gençleşmesi gerçekleşmedi. Sadece CHP yanlısı komutanlar tasfiye edildi. Ordu içinde bir süredir devam eden CHP ve DP'li subaylar çekişmesini şimdilik DP'li subaylar kazanmış oldu. ${ }^{13}$

DP iktidara geldiğinde korgeneral rütbesinde olan Gürler, 6 Mayıs'ta orduda yapılan düzenlemede tasfiye edilenler değil terfi edenler listesinde oldu. 7 Haziran'da bazı gazeteler Gürler'in Genelkurmay İkinci Başkanlığ 1 görevine getirildiğini yazd. ${ }^{14}$ Gerçekten de Nuri Yamut Genelkurmay Başkanı olmasının ardından İkinci Başkanlık görevine Kara Kuvvetleri Komutanlığı Kurmay Başkanı Gürler'i getirmek istemişti. Hatta Yamut'un atanmasının ardından aynı gün akşam Cumhurbaşkanı Bayar, Başbakan Menderes, Başbakan Yardımcısı Samet Ağaoğlu, Bayındırlık Bakanı Fahri Belen kendisine hayırlı olsun ziyareti gerçekleştirmiş ve burada uzun bir görüşme yapmışlardı. Ziyaret esnasında Yamut, Bayar ve Menderes'e Gürler'i takdim ederken İkinci Başkan olarak takdim edince, Bayar, Menderes'e dönerek “Ama bunu kararlaştırmamıştık" demiştir. Yamut, Gürler'in atanması konusunda bir oldubitti yapmak istemişti. Ancak bu atama gerçekleşmemiştir. ${ }^{15}$ Gazetelerde birkaç gün süren İkinci Başkan olarak Gürler'in atandığına dair haberlerin kaynağ 1 muhtemelen bu tereddütlerdir. 10 Haziran'dan itibaren gazeteler İkinci Başkanlığa artık Gürler'in değil Genelkurmay İkmal Dairesi Başkanı Zekai Okan'ın atandığını duyurmuşlardır. ${ }^{16}$

Orduda meydana gelen tasfiye kamuoyunda geniş yankı bulmuştur. Hükümet bu süreci olağan bir değişiklik olarak açıklasa da aslında bu ordudan gelebilecek bir müdahaleye karş1 alınan önlemdi. ${ }^{17}$ Yeni Sabah gazetesi 10 Haziran 1950 'de orduda son atama ve emeklilik kararları ile ilgili ortaya atılan iddialara yer vermiştir. Gazeteler yüksek komuta kademesinde yapılan değişikliğin 14 Mayıs yani seçimlerin yapıldığı akşam bazı generallerin Çankaya'ya giderek İnönü’ye bir emri olup olmadığını sormasından kaynaklandığı iddiasını yalanlanmış, ancak yapılan değişiklikle ordunun politikadan uzaklaştırılmasının hedeflendiğini belirtmişlerdir. CHP'den Şemsettin Günaltay da bu iddiaların gerçek olmadığını açıklamıştır. $\mathrm{Bu}$ yöndeki iddialar muhatapları tarafından daha sonra yalanlansa da oldukça gergin bir süreçte bunlar önemli iddialardı. Milliyetin haberine göre hükümet kanadından bir yetkili yapılan değişikliğin ordu içinde çok olumlu karşılandığını, belirtmiş bunu cesurca ve orduyu gençleştiren bir adım olarak övmüştür. ${ }^{18}$

Orduda görevden almalarla ilgili bir diğer iddia Milli Savunma Bakanlığı bütçesinde yapılması planlanan kesintiler nedeniyle Orgeneral Abdurrahman Nafiz Gürman ve bazı generaller ile hükümet arasında anlaşmazlığın çıktığı ile ilgiliydi. Bu konuda Zafer gazetesine

12 Eroğul, a.g.e., s. 97-100., Yeni İstanbul, 7 Haziran 1950

13 Özdağ, Menderes Döneminde Ordu-Siyaset İlişkileri, s. 84-87. Özdağ, Ordu-Siyaset İlişkisi Atatürk-İnönü Dönemleri, s. 166.

${ }^{14}$ Milliyet, 7 Haziran 1950.

${ }^{15}$ Özdağ, Menderes Döneminde Ordu-Siyaset İlişkileri, s.84-87., Özdağ, bu olayı Bekir Tunay'dan aktarmaktadır. Bkz. Bekir Tünay, Menderes Devri Anıları Gördüklerim, Duyduklarım, Bildiklerim, Nilüfer Matbaacılık, Ístanbul(Tarih yok), s. 97, 7-8 Haziran 1950 tarihli bazı gazetelerde Gürler'in II. Başkanlığa getirilmesinin beklendiği yazıyordu. Bknz: Zafer, 7 Haziran 1950. Yeni Sabah, 8 Haziran 1950, Akşam, 7 Haziran 1950.

${ }^{16}$ Yeni Sabah, 11 Haziran 1950.

${ }^{17}$ Mustafa Albayrak, Türk Siyasi Tarihinde Demokrat Parti 1946-1960, Phoenix Yayınları, Ankara 2004, s. 191192.

${ }^{18}$ Yeni Sabah, 10 Haziran 1950., Albayrak, a.g.e., s. 191-192., Ali Fuat Başgil, 27 Mayls Ihtilali ve Sebepleri Görüp Yaşadıklarım, Yağmur Yayınevi, İstanbul 2006, s. 150-151. Milliyet, 8 Haziran 1950.

\section{History Studies}


demeç veren Milli Savunma Bakanı Refik Şevket İnce, Milli Savunma Bakanlığı bütçesinde alınacak tedbirler ile ilgili asılsız iddiaların kamuoyunda rahatsızlık yarattığını, emir eri uygulamasının kalkmayacağını, sadece yeni düzenleme getirileceğini, elbise gibi ihtiyaçların karşılanmaya devam edeceğini belirtmiştir. ${ }^{19}$ İnce, ayrıca orduda son yapılan görevlendirmenin hükümetin anayasal hakkını kullanmasından ibaret olduğunu vurgulamıştır. ${ }^{20}$

Milliyet'ten Ali Naci Karacan, "Orduda Yapılan değişiklikler” başlıklı makalesinde değişikliğin Türk kamuoyunda bu kadar ilgi görüp yakından izlenmesinin normal olduğunu belirtilerek görev değişikliğinin ordunun bütçesinden yapılan kesintilerle birlikte gündeme geldiğini dile getirmiştir. Zafer gazetesi ise bunun DP'nin iktidara gelmesinin ardından gerçekleştirilen normal bir değişiklik olarak görülmesinden yanaydı. ${ }^{21}$ Ancak Menderes 15 Haziran 1950'de parti grubunda yaptığı konuşmada son dönemde yaşananlara değinerek CHP'nin orduyu DP aleyhine tahrik ettiğini iddia etmiştir. ${ }^{22}$ İnönü, bu değişiklikler karşısında soğukkanlılığını korumayı başarmış, ancak bürokraside de meydana gelen değişikliklerin ardından adeta meydan okuyan sert bir tutum içine girmiştir. Ordu ve bürokraside meydana gelen değişim, seçimlerin üzerinden bir ay geçmeden siyasi havanın gerilmesine neden olmuştur. $^{23}$

DP'nin iç politikaya yoğunlaştığı iktidarının ilk günlerinde Kore Savaşı patlak vermiştir. Kuzey Kore'ye bağlı uçakların 25 Haziran 1950'de Seul'e yaptığı saldırı ile başlayan çatışmalar kısa sürede ABD'nin de katıldığı bir topyekun savaş haline gelmiştir. Türk basını bu gelişmeleri komünistlerin Uzakdoğu'ya yayılmak için attığı bir adım olarak değerlendirmiş, Birleşmiş Milletlerin (BM) 27 Haziran 1950'de Güney Kore’ye müdahale kararını almıştır. Ardından Dışişleri Bakanı Köprülü, barışın korunması için BM’nin aldığ 1 karara destek olacaklarını ve Kore'ye asker gönderileceğini açıklamıştır. ${ }^{24}$

Türk askeri Kore'ye gitmesinin ardından pek çok sorunla karşılaşmıştır. Kore'deki

Türk birliğinin maaştan, Türkiye ile sağlıklı haberleşme kuramamaya kadar yaşadığı sorunlar basına yansımış, bu konu hükümette huzursuzluk yaratmıştır. Yaşanan sıkıntıların aşılamaması nedeniyle Kore'deki Türk tugayı askerleri de adeta "sahipsiz ve kimsesiz" kaldıklarını düşünmeye başlamıştır. ${ }^{25}$

$\mathrm{Bu}$ şikayetler üzerine, Türk birliğini denetlemek için Genelkurmay Teftiş Kurulu Başkanı Korgeneral Gürler görevlendirilmiştir. Gürler, kendisine verilen görev üzerine Hava Binbaşı Cevdet Zeyrek ile birlikte önce Tokyo’ya gitmiştir. Gürler, Teftiş Kurulu Başkanı olarak Kore'deki Türk Birliği'nin denetlenmesi görevinin kendisine verilmesinden dolayı gurur duyduğunu belirtmiş ve Türkiye'den ayrılmadan önce Cumhurbaşkanı, Başbakan, Milli Savunma Bakanı ve Genelkurmay Başkanı ile görüşmüştür. Gürler, Pan Amerikan Havayolları ile 24 Aralık'ta gerçekleştireceği yolculuk öncesi İstanbul'da yaptığı açıklamada ise bu ziyaretin Kore'deki Türk tugayının yerinde temin edilmeyen ihtiyaçlarını tespit için yapıldığını ve askerlere kendilerine karşı Türk kamuoyunda oluşan ilgiden bahsedeceğini söylemiştir. Gürler ayrıca son zamanlarda Türkiye'nin, Kore'deki asker sayısını azaltmak istediğine dair

\footnotetext{
${ }^{19}$ Zafer, 8 Haziran 1950., Yeni Sabah, 8 Haziran 1950, Milliyet, 8 Haziran 1950.

${ }^{20}$ Yeni Sabah, 11 Haziran 1950.

${ }^{21}$ Zafer, 9 Haziran 1950.

${ }^{22}$ Şevket Süreyya Aydemir, İhtilalin Mantı̆̆ ve 27 Mayıs İhtilali, Remzi Kitapevi, İstanbul 1973, s.181-182.

${ }^{23}$ Ahmet Emin Yalman, Yakın Tarihte Görüp Geçirdiklerim 1922-1971 C. II, Pera Yayıncılık, İstanbul 1997, s. 1531.

${ }^{24}$ Albayrak, a.g.e., s. 410.

${ }^{25}$ Cüneyt Güven, "Sebep ve Sonuçlarıyla Kore Savaşı ve Türkiye", Pamukkale Üniversitesi Sosyal Bilimler Enstitüsü, Denizli, 2007, s. 181-183. (Yayımlanmamış Yüksek Lisans Tezi)
} 
haberleri yalanlamış ve asker olduğu için Kore'de General Mac Arthur'u ziyaret edeceğini belirtmiştir. ${ }^{26}$

Gürler gider gitmez göreve başlamış Kore'deki birlikleri denetlemesi esnasında yaptığı konuşmada, özgür dünyanın Türk askerinin kahramanlığını övdüğünü, Kore’ye Türk askerlerinin dertlerini dinlemeye ve anayurdun sevgisini sunmaya geldiğini belirtmiştir. ${ }^{27}$ Gürler, Kore'de göreve başlar başlamaz Genelkurmay Başkanlığı öncelikli olarak talepleri iletmiştir. Gürler, Kore'deki personelin dört aydır maaş alamadığını, derhal maaşların gönderilmesini, yaralılardan Türkiye'ye dönmesi gereken takriben 120 personelin derhal naklinin sağlanmasını, bu konuda ABD'li yetkililerin yeni muharebelerde gelecek yaralılar için Türk yetkililerini sıkıştırdığını, Japonya'daki üç ayrı uzak hastanede yatan yaralı ve hastaların dertlerini doktorlara anlatamadıklarını, bu nedenle tercümana ihtiyaç olduğunu, diğer ülkelerin hastanede yatan hastalarına hususi heyetler vasıtasıyla hediyeler gönderdiklerini, ancak bu güne kadar Türkiye'den birer paket sigara haricinde hiçbir hediyenin gelmediğini, acilen uçakla yaralılara incir, üzüm, lokum ve kitap gibi hediyelerin gönderilmesini istemiştir. Gürler'in göreve başlar başlamaz acil olarak ilettiğ bu istekleri için çalışmalar başlatılmıştır. Gürler ise görevi süresince Kore'deki Türk Tugayı'nı denetlemiş, askeri birliklere ziyaretlerde bulunmuş, 11 Ocak'ta Tokyo'ya giderek Japonya'daki yaralıları ziyaret etmiştir. ${ }^{28}$ Gürler, 26 Ocak 1951 'de Kore'ye tercümanlık yapması için gönderilen 10 Türk yedek subay ile görüşmesinin ardından Türkiye'ye dönmüştür. Dönüşünde yaptığı açıklamada Kore'deki Türk tugayının ilk çatışmalarda edindiği tecrübenin ardından "kılıcını daha iyi bilemiş şekilde" yeni muhabereler için sırasını beklendiğini ifade edilmiştir. ${ }^{29}$ Ankara'da Cumhurbaşkanı Bayar ile bizzat görüşerek Kore'deki izlenimleri hakkında detaylı bilgi vermiştir. ${ }^{30}$ Gürler aynı zamanda Kore'deki izlenimlerini 1 Şubat 1951'de radyoda yaptığı konuşma ile halka da anlatmıştır. ${ }^{31}$

Gürler, ABD'li askerler ile görevi gereği yakın temasına Adana İncirlik'te kurulacak olan havaalanı çalışmaları esnasında devam etmiștir. Gürler ve Hava Kuvvetleri Kurmay Başkanı İhsan Ongun 15 Nisan 1951'de ABD'li general ve uzmanlarla birlikte burada incelemelerde bulunmuşlardır. ${ }^{32}$ Bayar'ın Mersin'e 22 Mayıs 1951'de yaptığı ziyaret esnasında kendini karşılayanlar arasında Üçüncü Ordu Komutan Vekili Korgeneral Gürler de vardır. ${ }^{33}$ Gürler 26 Mayıs 1951'de bu defa İzmir'e giden Bayar'ı İkinci Ordu Müfettiş Vekili olarak karşılamıştır. ${ }^{34}$ Kara Kuvvetleri Komutanı Orgeneral Kurtcepe Noyan'ın ölümünün ardından 2. Ordu Komutanı Korgeneral Gürler en kuvvetli aday olarak ortaya çıkmıştır. Bu atama gerçekleşmemiş ancak Gürler, Bayar ve Menderes'e 2. Ordu Müfettişi olarak yurt gezilerinde eşlik etmeye devam etmiştir. ${ }^{35}$ Gürler, İskenderun'da Suriye'nin Lazkiye şehrinden gelerek planlı bir şekilde kız kaçırma bahanesi ile başlayan olaylara ilk müdahale eden komutan olmuştur. Yanında Jandarma Genel Komutanı ile birlikte askeri uçak ile olayların yaşandığı İskenderun'a gitmiştir. ${ }^{36}$ Bayar' ın Konya'ya gerçekleştirdiği ilk resmi ziyarette karşılama töreninde II. Ordu Müfettişi Korgeneral Gürler yer almıştır. ${ }^{37}$ TBMM Başkanı Refik

\footnotetext{
${ }^{26}$ Milliyet, 20-22-23 Aralık 1950.

${ }^{27}$ Milliyet, 2 Ocak 1951.

${ }^{28}$ Güven, a.g.t., s. 181-183., BCA, Fon Kodu. 030-01-01-00, Yer Adı: 56-345-5, 30 Aralık 1950.

${ }^{29}$ Milliyet, 25-27 Ocak 1951.

${ }^{30}$ Milliyet, 29 Ocak 1951.

${ }^{31}$ Milliyet, 2 Şubat 1951.

${ }^{32}$ Milliyet, 16 Nisan 1951.

${ }^{33}$ Milliyet, 23 Mayıs 1951 .

${ }^{34}$ Milliyet, 26 Mayis 1951.

${ }^{35}$ Milliyet, 30 Mayıs 1951.

${ }^{36}$ Milliyet, 31 Temmuz 1951.

${ }^{37}$ Ayın Tarihi, Haziran 1951, http://ayintarihi.iletisim.gov.tr/turkce
} 
Koraltan'ın Kayseri ziyareti sonrası askeri tören ile uğurlanması törenini Ordu Müfettişi Gürler tarafından düzenlenmiştir. ${ }^{38}$

Gürler 24 Ağustos 1951'de Şükrü Kanatlı ve Nurettin Baransel ile birlikte korgenerallikten, Orgeneralliğe, terfi etmiştir. ${ }^{39}$ Ardından Şükrü Kanatlı Kara Kuvvetleri Komutanlığı'na, Zekai Okan 1. Ordu Komutanlığı'na, Gürler'de Genelkurmay İkinci Başkanlığına atanmıştır. ${ }^{40}$ Gürler, bu göreve gelmesinin ardından Başbakan başkanlığında toplanan Milli Savunma Yüksek Kurulu'na katılmıştır. ${ }^{41}$ Başbakanlıkta Menderes ile Amerikan Askeri Yardım Heyeti Başkanı General Arnold ile gerçekleşen görüşmeye Genelkurmay Başkanı ile birlikte katılmıştır. ${ }^{42}$

Türkiye'nin NATO'ya üye olması sürecinde yürütülen üst düzey görüşmelere Gürler de katılmıştır. Türkiye ve Yunanistan'ın NATO'ya kabulü ile ilgili 20 Şubat 1952'de Lizbon'da gerçekleştirilen NATO Konseyi toplantısı gerçekleşmiştir. Türkiye ve Yunanistan bu toplantıda resmen NATO'ya üyesi olmuştur. Gürler, 20 Şubat 1952'de gerçekleştirilen NATO Konseyi toplantısına Dışişleri Bakanı Köprülü başkanlığındaki heyette, Fatin Rüştü Zorlu ile birlikte katılmıştır. Gürler bu toplantı esnasında NATO üye ülkelerin askeri ve sivil üyeleri ile görüşmeler yapmıştır. Üyeliğin ardında Türkiye'nin hangi komutanlıklar aracılığı ile NATO Avrupa Ordusu Komutanlığı (SHAPE) karargâhına bağlanacağı gibi detaylar kalmıştır. ${ }^{43}$

Gürler, 29 Şubat 1952'de NATO’nun Napoli Karargahını da ittifaka yeni üye olan
'

HISTORY STUDIES

845

Volume 11

Issue 3

June

2019 bä̧skanı olarak pek çok toplantıya katılmış, Eisenhower ile görüşmüsş, Türkiye'ye döndügünde bu görüşmeler ile ilgili olarak Genelkurmay Başkanı Nuri Yamut ve Milli Savunma Bakanı Hulusi Köymen'e bilgi vermiştir. ${ }^{44}$ Eisenhower'ın 3 Mart 1952'deki Türkiye ziyareti esnasında onu karşılayanlar arasında Gürler de vardır. Dışişleri Bakanlığı'nda Köprülü, Yamut, Gürler ve Eisenhower bir toplantı yapmışlardır. Ardından Başbakanlıkta daha geniş bir heyet ile gerçekleşen görüşmelerde Gürler'de yer almıştır. ${ }^{45}$

NATO'nun Güney Avrupa Kuvvetleri Komutanı Amiral Robert Carney'in 12 Mart 1952'de Ankara'ya yaptığı ziyaret esnasında onu karşılayanlar arasında Gürler de vardır. Bu görüşme, NATO'ya yeni katılan Türk ve Yunan kuvvetlerinin hangi komutanlığın emrine verileceği tartışmaları bakımından önemliydi. Türk ve Yunan Hükümeti, İtalyan komutanın altında değil Eisenhower'ın komutasına bağlanmak istiyordu. Uzun süren görüşmeler sonrası bu sorun Türkiye ve Yunanistan'ın istediği şekilde çözülmüş, iki ülke NATO'nun Güney Avrupa Kuvvetleri Komutanlığı'na bağlanmıştır. ${ }^{46}$ Gürler, 1952'de ABD ve Yunanistan'dan gelen askeri heyetleri ağırlamış, NATO Orduları Hava Kuvvetleri Komutanı yardımcısı General Saunders'in ziyareti esnasında Ankara'da genelkurmayda gerçekleşen görüşmelere katılmıştır. ${ }^{47}$ Amiral Carney'in görüşmeler yapmak ve Türk ordusunun durumunu daha yakından görmek için 17 Mayıs 1952'de gerçekleştirdiği ziyarette onu yine Gürler yalnız

\footnotetext{
${ }_{38}^{38}$ Ayın Tarihi, Aralık 1951, http://ayintarihi.iletisim.gov.tr/turkce

${ }^{39}$ Milliyet, 26 Ağustos 1951.

${ }^{40}$ Milliyet, 12-13 Aralık 1951.

${ }^{41}$ Milliyet, 22 Ocak 1952.

${ }^{42}$ Milliyet, 30 Ocak 1952.

${ }^{43}$ Milliyet, 19 Şubat 1952., İsmail Soysal, Soğuk Savaş Dönemi ve Türkiye Olaylar Kronolojisi: 1945-1975, İsis Yayımcilik, İstanbul 1997, s. 141.

${ }_{45}^{44}$ Milliyet, 1-3 Mart 1952.

${ }^{45}$ Milliyet, 4 Mart 1952. Ayın Tarihi, 3 Mart 1952, http://ayintarihi.iletisim.gov.tr/turkce

${ }^{46}$ Milliyet, 12 Mart 1952., Erol Mütercimler, Mim Kemal Öke, Düşler ve Entrikalar Demokrat Parti Dönemi Türk Dış Politikası, Alfa Yayıncılık, İstanbul 2004, s. 107.

${ }^{47}$ Milliyet, 20-23 Nisan 1952.
} 
bırakmamıştır. Carney’i Etimesgut Hava alanında eşi Emel Gürler ile karşılayan Gürler, İstanbul, Ankara, Gölcük, İskenderun, Erzurum'da yanında yer almış 25 Mayıs'a kadar ona eşlik etmiştir. ${ }^{48}$

NATO Orduları Başkomutan Yardımcısı Mareşal Montgomery’i gerçekleştirdiği ziyaret sonras1 15 Mayıs 1952'de Etimesgut Havaalanından Paris'e gitmek üzere uğurlayanlar arasında Genelkurmay Başkanı Orgeneral Nuri Yamut, İkinci Başkan Orgeneral Gürler, kuvvet komutanlarının yanında $\mathrm{ABD}$ ve İngiltere büyükelçileri, Amerikan Askerî Yardım Heyeti Başkanı General Arnold vardır. ${ }^{49}$ Gürler görevden alınmadan önce Türkiye'nin NATO savunma sistemindeki yeri ile ilgili kritik toplantılara katılmayı sürdürmüştür. ${ }^{50}$

\section{Gürler'in Emekliye Sevk Edilmesi}

Gürler'in Genelkurmay II. Başkanı olarak hükümet üyeleri ile sık sık bir araya geldiği bu dönemde DP, ordu içinde yeni reform programları hazırlıyordu. Alt rütbeli subaylar için DP'nin iktidara geldiğinden beri ordu içinde yaptığı reformlar yeterli değildi. Generaller arasında yeni bir temizlik yapılmasını istiyorlardı. Seyfi Kurtbek, Kasım 1952'de Milli Savunma Bakanlı̆̆g'na atanınca bu konuda somut adımlar atmaya karar verdi. Bayar ve Menderes başlangıçta bu reformları desteklediler. Ancak kısa süre sonra Kurtbek'in planının orduyu kontrolü altına alarak iktidarı topyekun ele geçirmek olduğuna dair söylentiler çıkınca Menderes, generallerin çok büyük tepkisini çekecek yeni tasfiye hareketinden vazgeçti. ${ }^{51} \mathrm{Bu}$ esnada 14 Mayıs 1950 seçimlerinde DP'nin iktidarı ele almasına sıcak bakmasa da saygı duyan pek çok subay DP'ye cephe almaya başlamıştır. DP saflarında siyasete giren ve 6 Haziran 1950 'de orduda yapılan tasfiyede aktif rol oynayan Fahri Belen, Seyfi Kurtbek gibi bazı emekli subaylar, hükümete ağır ithamlarda bulunarak görevden ayrılmışlardır. Bu ayrılışlarla birlikte DP hükümeti içinde orduyu iyi tanıyanların sayısı azalmıştır. Üstelik subaylar arasında, Türk siyasal kültüründe sahip oldukları rolü kaybetmeye başladıkları düşüncesi daha hızlı yayılmaya başlamıştır. $^{52}$

Ordu ile DP arasında yaşanan gerilimden kısa süre sonra Gürler de payını almıştır. Gürler, II. Başkanlık görevine gelmesinin ardından NATO ile askeri konuları müzakere eden en önemli isimlerden biri olmuştur. NATO ittifakı içinde Türkiye'nin yeri ve buradan alınacak askeri malzemenin niteliğine kadar pek çok konuda Gürler ile Menderes ve Zorlu arasında derin görüş ayrılıkları ortaya çıkmıştır. Gürler ve bazı generaller ABD'den alınacak silahlar konusunda titiz davranmak ve Türkiye'yi ABD'nin eskimiş silah deposu haline getirmek istemiyorlardı. Hükümet kanadı Türk ordusunun tamamen NATO komutasına girmesinde bir sakınca görmezken, askerler bu konuda isteksizdi. ${ }^{53}$ Öte yandan DP hükümeti ile Gürler arasında bir güven problemi ortaya çıkmıştır. Emekli Orgeneral Bedrettin Demirel, Temmuz 1987'de verdiği mülakatta Türkiye'de başbakanların kendi güveneceği ekiple çalışmak istediğini ve bunun onların hakkı olduğunu söylerken, Gürler'i örnek olarak vermiştir. Gürler DP tarafindan bir süre sonra istenmeyen adam haline gelmiştir. Abdurrahman Nafiz Paşa, Ali Fethi Esener gibi DP ile yakın ancak bir süre sonra muhalif tavırları nedeniyle emekliye sevk edilen generallerin kaderini paylaşarak erken emekli edilmiştir. ${ }^{54}$

\footnotetext{
${ }^{48}$ Milliyet, 19 Mayıs 1952., Ayın Tarihi, Mart 1952, http://ayintarihi.iletisim.gov.tr/turkce

49 Ayın Tarihi, Mayıs 1952, http://ayintarihi.iletisim.gov.tr/turkce

50 Foreign Relations of the United States (FRUS), 1952-19541, (Washington, 1969), Vol. VIII, https://hstory.state.gov/hstorcaldocuments/frus1952-54v08/d467

${ }^{51}$ Hale, a.g.e., s.93-94.

${ }^{52}$ Hale, a.g.e., s.94. Özdağ, Menderes Döneminde Ordu-Siyaset İlişkileri, s. 84-87.

${ }^{53}$ Milliyet, 30 Nisan 1968.

${ }^{54}$ Milliyet, 5 Temmuz 1987.
} 
DP iktidara geldikten kısa süre sonra orduda yaptığ tasfiyelerle muhtemel bir müdahalenin önüne geçmeyi planlamıştır. Ancak iktidarının ikinci yılı dolduğunda yeni bir tasfiyeye mecbur kalmıştır. Bu defa orduda müdahale yapmasından endişe edilen kişi Genelkurmay II. Başkanı Orgeneral Gürler olmuştur. Orgeneral Gürler 25 Temmuz 1952'de görevden alınmıştır.

Gürler 1951'de DP'nin iktidara gelmesinin ardından orgeneral olmuş ve Genelkurmay İkinci Başkanlığına getirilmişti. Ancak bu süreçte ona göre DP iktidarı "Atatürk inkılaplarından tavizler vermeye" başlamıştı. Eşi Emel Gürler aynı günlerde DP hükümetini her firsatta sert bir şekilde eleştirmiştir. Bunun üzerine hükümet, Samet Ağaoğlu aracılı̆̆g ile Gürler'e eşinin siyasi faaliyetleri ve eleştirilerini, ayrıca onunla aynı fikirde olup olmadığını sormuştur. Gürler de açık bir şekilde eşi ile aynı fikirde olduğunu ve DP hükümetinin bazı uygulamalarda hata yaptığını, düzeltmesi gerektiğini söylemiştir. Bunun üzerine DP politikasını değiştirmemiş ancak Gürler'i 1952'de henüz 56 yaşındayken emekliye sevk etmiştir. ${ }^{55}$

Misır'da 23 Temmuz 1952'de meydana gelen Hür Subaylar darbesinin üzerinden daha bir hafta dahi geçmeden meydana gelen bu görevden almanın zamanlaması İngiltere'ye göre oldukça ilginçtir. Çünkü DP Mısır'da Hür Subayla Hareketi'nin gerçekleştirdiği darbe ile ilk defa bir darbenin sarsıcı sonuçlarını gözlemleme imkânı bulduğu esnada bu görevden alma gerçekleşmiştir. $^{56}$

İngiltere'nin Ankara Büyükelçisi Alexander Knox Helm, Türk ordusunun 30 Temmuz

HISTORY

STUDIES

847

Volume 11

Issue 3

June

2019

1952 akşamı Ayaş’ta gerçekleşen tatbikatını izlemek için gittiğinde Türk Hava Kuvvetlerinden Eskişehir 1. Hava Kuvvetleri Komutanı General Tekin Arıburun'un kendisi ile görüşmek istediğini bir subay aracılığı ile iletince ve görüşmede uzun uzun Gürler'in görevden alınması sürecini anlatınca İngiltere bu olayı daha yakından takip etmeye başlamıştır. Büyükelçi Helm, Arıburun'u yakından tanıdığını belirterek bu görüşmeyi ülkesine rapor etmiştir. Helm raporunda Arıburun'un gayet soğukkanlı bir șekilde Gürler'in görevden alınmasının politik bir karar olduğunu söylediğini aktarmıştır. Arıburun'a göre Gürler son zamanlarda gazetecilerle sürekli temas halinde ve yakın dostluk kuran popüler bir generaldi. Türk ordusundaki düşük rütbeli subaylar arasında halen oldukça popüler olan İnönü’nün Gürler ile yakın ilişkisi hükümeti rahatsız etmiști. DP Hükümeti ordu içinde kendisine karşı bir hareketin hazırlandığını düşünüyordu. Mısır'da gerçekleşen darbenin Türkiye'de bazı subayları heyecanlandırarak esin kaynağ1 olacağ 1 ve harekete geçeceklerinden şüphelenerek Gürler, görevinden alınmıştı. Arıburun, İngiliz Büyükelçi ile yaptığı konuşma sonunda "eğer birisi politikaya bulaştıysa, çok dikkatli olmalıdır" sözü ile Gürler'in siyasi bir işe bulaştığını iddia etmiştir. Büyükelçi Helm, Arıburun ile yaptığı bu görüşmeyi 20 Ağustos'ta ABD'ye dönmeden önce ABD'li General John K. Cannon'a aktarmıştır. Cannon ile yalnız kaldığı esnada Arıburun ile konuşulanları anlatan büyükelçiye Cannon, Gürler hakkındaki düşüncelerini aktarmıştır. Cannon, Gürler'in İnönü'nün güçlü bir adamı ve Türk ordusunun NATO Avrupa Ordusu Komutanlığı'na bağlanmasına taraftar bir komutan olarak ABD'liler tarafindan desteklendiğini belirtmiştir. Ayrıca ABD Askeri Yardım Misyonu Komutanı General Arnold'un Gürler'in yerine Zekai Okan'ın getirilmesine son derece sinirlendiğini belirtmiştir. Çünkü Arnold'a göre Gürler, Türk generaller içinde en iyi üst düzey generallerden biriydi. ${ }^{57}$ Gürler'in görevden alınmasında eşi

\footnotetext{
${ }^{55}$ Akis, 30 Haziran 1960, s.17-18, 20.

${ }^{56}$ Cüneyt Arcayürek, Yeni İktidar Yeni Dönem 1951-1954, Bilgi Yayınevi Ankara 1984, s.89.

57 N.A., FO, 195/2686/10719G, Ankara Büyükelçiliği'nden, Dışişleri Bakanlığı'na, 31 Temmuz 1952. Tekin Arıburun 1952'de İngiltere Büyükelçisi ile yaptığı görüşmede Gürler'in eşi Emel Gürler'in siyasi faaliyetlerinin etkisiyle görevden alındığını belirtmiş ancak kendi eşi Perihan Arıburun 1957 XI. Dönem TBMM'de DP İzmir milletvekili olarak seçilmiştir. Üstelik Perihan Arıburun TBMM kürsüsünden DP'nin son Genelkurmay Başkanı Rüştü Erdalhun'un görev süresinin uzatılması ile ilgili olan kanun teklifine açık bir şekilde Erdalhun'un ismini
} 
Emel Gürler'in CHP'de siyaset yapmasının etkili olduğu iddiası aslında yeterli dayanaktan yoksundu. Çünkü Emel Gürler DP iktidara gelmeden de CHP'de siyaset yapmaktaydı. DP'nin iktidara geldiği 14 Mayıs 1950 seçimlerinde 10 adet Kars milletvekilliği için başvuruda bulunan 300 aday içinde eşi o dönemde korgeneral olan Emel Gürler'de vardı. 1909 doğumlu olan Emel Gürler, Burdur Lisesi'nden mezun olmuş Burdur, Konya ve Kars Halkevlerinde aktif bir şekilde çalışmıştı. Ayrıca Kars CHP İl Başkanlığı, Kars Yardımseverler Derneği kurucu başkanı, CHP İstanbul il teşkilatında propaganda kolu üyesi, CHP Eminönü Kadınlar Kolu Başkanı, İstanbul Yardımseverler Merkez idare kurulu üyesi ve veznedarı, İstanbul Kadınlar Birliği Heyeti İkinci Başkanı ve birinci başkanlığı, Ankara Saraçoğlu CHP Ocă̆1 Müteşebbis Heyeti Başkanlığ gibi aktif siyasetin içinde pek çok sivil toplum kuruluşunda görevde bulunmuş bir isimdi. ${ }^{58}$ Emel Gürler'in CHP'li olduğu hatta subay eşlerini CHP'ye oy vermesi için tehdit ettiği Ankara'da birçok kesimce iddia edilmekteydi. ${ }^{59}$

İngiliz Askeri Ataşesi, Dışişleri Bakanlığı'na yolladığı telgrafta ise Türk Kara Kuvvetlerinde bir protokol subayının Gürler'in "sepetlendiğini" yani kovulduğunu söylediğini aktarmıştır. Bahsi geçen subay Gürler'in karısının politika ile meşgul olması nedeniyle görevden alındığı iddialarını tekrarlamıştır. Genelkurmay Başkanı Yamut'un yaveri Albay Atalay ise Gürler'in görevden alınmasıyla ilgili yeni detaylar anlatmıştır. Buna göre Gürler, görevden alınınca Zekai Okan'ın yönlendirmesi ile I. Ordu Komutanlığı görevi için gece yarısı Ankara'dan ayrılarak İstanbul'a gitmiştir. Albay Atalay'a göre Zekai Okan, Gürler'i rahatlatmak ve tepkisini azaltmak amacıyla onun I. Ordu Komutanlığı'nın başına atandığını söylemişti. Gürler'den önce İkinci Başkanlık görevini üstlenen Zekai Okan, 7 ay sonra tekrar bu göreve gelmekten dolayı oldukça mutluydu. İngiliz Askeri Ataşesi raporunda Gürler'in kariyeri ile ilgili önemli bilgiler de paylaşmıştır. Rapora göre Gürler, DP iktidarı ile yükselen ve önü açılan komutanlardan biriydi. II. Ordu Komutanı olarak uzun süre sahada görev yapmasının ardından ABD’nin tavsiyesi üzerine Genelkurmay İkinci Başkanı olarak atanmıştı. Üstelik İngiliz Askeri Ataşesine göre çok yakın bir zamanda bir şey olmadıysa ABD’lilerin, Gürler hakkındaki olumlu görüşleri değişmemişti. Arnold ve ABD Askeri Misyonu, Gürler ile çalışmaktan memnundu. İngiliz askeri yetkiler de onun ayrılmasından dolayı üzgündü. Çünkü Gürler'in Türk generaller arasında gerçekten en zekisi olduğuna inanıyorlardı. Pakistan Askeri Ataşesine göre ise Gürler'in görevden alınmasında onun ordu üzerindeki etkisi ve itibarı ile ilgili dedikoduların Menderes'e kadar ulaşması etkili olmuştu. ${ }^{60}$

İngiliz Dışişleri Bakanlığı'nda yapılan değerlendirmenin ardından İngiltere'nin Ankara Büyükelçisine verilen cevapta, Gürler'in tasfiye edilmesinde etkili olan kişinin, Gürler'den önce Genelkurmay İkinci Başkanlığı görevini yürüten I. Ordu Komutanı Zekai Okan olduğu belirtilmiştir. İngilizlere göre Okan, sessiz ve pasif bir generaldi. Gürler, CHP'ye oldukça yakın bir isim ve karısı Emel Gürler'in parti içinde güçlü bir isim olmasına rağmen, DP iktidara geldiğinde sıkıntı yaşamayan komutanlardan biri olmuştu. II. Ordu Komutanlığı ve Genelkurmay İkinci Başkan Yardımcılı̆̆ 1 görevine getirilmesinde ABD’nin tavsiyeleri etkili olmuştu. Onun görevden alınması esasında ABD'ye bir darbeydi ve bu görevden alma genel bir hoşnutsuzluğa neden olmuştu. Çünkü hem İngiliz hem de ABD'li yetkililer Gürler'e Okan'dan

zikrederek destek istemiştir. Faaliyetleri hakkında bkzn. Filiz Çolak, "Demokrat Parti Döneminde TBMM'deki Kadın Milletvekilleri ve Meclisteki Faaliyetler (1950-1960)", Tarih Okulu Dergisi (TOD) Journal of History School (JOHS), Aralık 2017, Y11 10, Sayı XXXII, ss. 115-158s. , TBMM Zabıt Ceridesi, Devre: XI, Cilt: 9, İçtima: 2, 8 Haziran 1959, s. 599.

${ }^{58}$ Cengiz Atlı, "1950 Yılı Kars Milletvekilliği ve Belediye Seçimleri”, Ankara Üniversitesi Türk Inkılap Tarihi Enstitüsü Atatürk Yolu Dergisi, Sayı: 51, Bahar:2013, s. 522-526., BCA, Fon Kodu. 490-01-00-00, Yer Adı: 3601242-3, 18 Mart 1950.

59 Tünay, a.g.e., s. 97.

${ }^{60}$ N.A., FO, 195/2686/W10719/8/52G, 28 Temmuz 1952.

\section{History Studies}


daha fazla değer veriyordu. İngiltere açısından bu olay aydınlatılmalı, ABD ve İngiliz yetkililerin iletişiminin iyi olduğu bu komutanın görevden alınmasının bu ülkelere karşı bir tavır olup olmadığı açı̆̆a çıkarılmalıydı. İngiltere'ye göre Gürler'in görevden alınması ile ilgili çeşitli spekülasyonlar vardı. ABD'li komutanların özellikle de General Arnold tarafından desteklenen ve önem verilen kişi olan Gürler'in görevden alınmasını ABD'ye karşı bir tavır olarak değerlendirmek ise pek mümkün gözükmüyordu. Çünkü DP Hükümeti’nin ABD ile ilişkilerini bozacak ve onları tepkisini çekecek herhangi bir girişimde bulunması İngilizlere göre pek olası değildi. Türkiye ile ABD arasındaki ilişkilerde Gürler'in görevden alınmasından dolayı henüz bir sorun çıkmamıştı. Dışişleri Bakanlığı'nda yapılan değerlendirmeye göre yine de bu görevden almada Menderes ile Arnold ve Carney arasındaki görüş ayrılıklarının etkisini göz ardı etmemek gerekiyordu. Çünkü Türk Hükümeti, ABD askeri misyonu ile çalışırken kendilerine daha fazla yetki alanı açılacağını düşünüyordu. İngiliz Büyükelçi’ye göre ise Gürler'in görevden alınmasında Genelkurmay Başkanı Yamut'un emekliliği arasında bağlantı vardı. Ağustos 1952 'de emekli olacak olan Yamut'un ardından en güçlü adaylardan biri Gürler'di. Menderes ve Köprülü daha önce olduğu gibi ABD'nin devreye girerek Gürler'in genelkurmay başkanı olmasını isteyebilirlerdi. Bu nedenle Gürler görevden alınarak, ABD’nin sürece müdahalesi engellenmiş, böylece bir krizin önüne geçilmiş oldu. Büyükelçi Helm'e göre bu dış faktörlerin yanında başka faktörler de Gürler'in görevden alınmasında etkili olmuş olabilirdi. Son zamanlarda Menderes'in diktatoryal eğilimlerinin arttığı görülüyordu. Menderes her şeyin kendisine sorulmasını istiyordu. Dışişleri Bakanı Köprülü onun gözünde itaatkar bir memurdu. Menderes, Dışişleri Bakanlığa bizzat emir veriyor ve insanların özgür iradeleri ile karar vermesine izin vermiyordu. Helm'e göre Gürler, oldukça güçlü, kanaatleri olan, özgür düşünebilen bir adamdı. Helm tek başına bunun etkili olmasa bile Menderes’in, Gürler'in güçlü pozisyonuna ve yeteneklerine güvenmediğini, onu bu nedenle görevden alınmış olabileceğini düşünüyordu. Üstelik $\mathrm{ABD}$, Yamut döneminde Türk generalleri üzerinde etkili olmaya başlamıştı. Eğer Gürler Genelkurmay Başkanı olsaydı, ABD'liler onunla daha güçlü bir işbirliği sağlayabileceklerdi. ABD'liler Gürler'e verdikleri değere rağmen, onun iç politikadaki durumu yani İnönü ve CHP ile yakınlığı nedeniyle DP hükümetinin eylemini meşru görerek itirazda bulunmamışladır. ${ }^{61}$

İngiliz Dışişleri Bakanlığı'nda Ankara'dan gelen rapor üzerine yapılan değerlendirmeler sonrası, Gürler'in görevden alınmasında ABD askeri misyonu ile yakınlık veya Türk ordusunun NATO'da hangi komutanlık altında görev yapacağ 1 ile ilgili anlaşmazlıklardan kaynaklandığına dair bir kanıt olmadığını sonucuna varılmıştır. Bu aşamada İngilizlere göre Gürler'in neden görevden alındığı ve bundan sonraki görevinin ne olduğu açık değildi. İlk önce onun I. Ordu Komutanlığı'na veya Türkiye'nin NATO Askeri Temsilcisi olarak atanması gündeme gelmişti. Ancak DP Hükümeti'nin Amiral Ulusu'dan çok memnun olması ve Gürler'in İngilizce konusunda yetersiz olması nedeniyle İngilizlere göre bu pek mümkün değildi. ${ }^{62}$

\section{CHP Üyesi Olarak Faaliyetleri}

Gürler zorunlu emekliliğinin ilk günlerinde siyasi faaliyetlerden uzak durmuştur. Emekliliğinin ardından Kadıköy Ortaokulu'nda 4 Mart 1953'te kahramanlık günü münasebetiyle bir konferans vermiş ${ }^{63}, 17$ Mart 1953'te Milli Türk Talebe Birliği tarafindan Çanakkale Haftası münasebetiyle Eminönü Halkevi’nde düzenlenen törene katılmıştır. Burada

\footnotetext{
${ }^{61}$ N.A., FO, 195/2686/10719G/10719/81/52G, 29 Temmuz 1952.

${ }^{62}$ N.A., FO, 195/2686/W10719/8/52G, 28 Temmuz 1952.

${ }^{63}$ Milliyet, 5 Mart 1953.
} 
kısa bir konuşma yapan Gürler, Çanakkale şehitlerine duyulan minneti ifade etmiştir. ${ }^{64}$ Gürler, 9 Kasım 1953'te CHP Kızıltoprak Ocağına giderek partiye üye olmuş, böylece CHP'de aktif siyasete resmen başlamıștır. ${ }^{65}$ Aktif siyasi hayata başlamasının ardından, 18 Şubat 1954 'te CHP İstanbul İl Kongresi'ne Kazım Özalp ve Hüseyin Cahit ile birlikte katılmıştır. ${ }^{66}$ Gürler'in İstanbul'dan milletvekili adaylığı için 27 Mart 1954'te yoklama yapılmıştır. ${ }^{67}$ Gürler ve Eşi Emel Gürler, 1954 seçimlerinde CHP'den milletvekili adayları içinde yer almıştır. ${ }^{68}$

1954 seçimlerinde Gürler'le birlikte CHP'nin aday listelerinde ordundan ayrılan pek çok subay yer almıştır. Bunların arasında eski Hava Kuvvetleri Komutanı Zeki Doğan, eski Genelkurmay Başkanı Abdurrahman Nafiz Gürman, General Ali Fuat Erden bulunuyordu. ${ }^{69}$ Gürler, 1954 seçimlerinde CHP'nin İstanbul'daki yirmi dört adayından biri olmuştur. ${ }^{70} \mathrm{CHP}$ saflarında aktif bir şekilde seçim çalışmalarına da katılmış, Silivri'de 26 Nisan 1954'de gerçekleşen seçim toplantısında konuşarak DP iktidarının dört yıllık icraatlarını eleştirmiştir. ${ }^{71}$ Gürler ve eşi 1954 seçimlerinde milletvekili seçilememiş ancak Gürler, 30 Temmuz 1954'te CHP'nin 30 kişilik parti meclisine girmiştir. ${ }^{72} 15$ Mart 1955 'te gerçekleştirilen CHP İstanbul il kongresinde ise il başkanlığı için aday olmuştur. ${ }^{73} 24$ Mayıs 1956'da yapılan CHP'nin 12. Kurultayı'nda yeniden parti meclisine seçilmiştir. ${ }^{74}$

1955 yılında iç politikada meydana gelen en önemli olay 6-7 Eylül Olayları olmuştur. Olayların ardından İstanbul'da sıkıyönetim ilan edilmiştir. İstanbul Sıkıyönetim Komutanlığına Korgeneral Nurettin Aknoz atanmıştır. ${ }^{75}$ Gürler bu süreçte 6-7 Eylül Olayları esnasında CHP yönetimi ile İstanbul Sıkı Yönetim Komutanlığı arasındaki iletişimi sağlamıştır. Çünkü Sıkıyönetim Komutanı Nurettin Aknoz, Gürler'in yanında görev yapmış ve eski komutanına çok saygı duyan bir isimdir. ${ }^{76}$ Aknoz ile Gürler arasındaki yakın ilişki Sıkı Yönetim Komutanlığı boyunca sürmüştür. Bu sayede İnönü'nün İstanbul'da sıkıyönetim devam ederken kapatılan gazeteleri ziyaret etmek gibi pek çok faaliyette bulunması kolaylaşmıştır. Hatta Ekim 1955 'te İstanbul'da CHP Parti Meclisi toplantıları yapılması planlanmıştı. Ancak İstanbul'da sıkıyönetim vardı. S1kıyönetim devam ederken Aknoz, CHP'li yetkililerin üst düzey toplantılarına izin vermişti. Ancak parti meclisi toplantısı daha kapsamlı bir işti ve toplantı sonrası bir bildiri yayınlanıyordu. Bu bildirilerde hükümetin politikalarının eleştirilmesi olağand1. Bu nedenle iş askerin aldığ 1 tedbirler çerçevesinde partinin kapatılmasına kadar varabilirdi. İnönü buna ihtimal vermese de tedbiri elden bırakmayıp parti meclisini sıkıyönetim bölgesi dışında Bursa'da topladı. Aknoz bu süreçte Gürler ile sürekli temasta olmayı sürdürdü. CHP'nin İstanbul'daki faaliyetlerine çok fazla müdahalede bulunmadı. Örneğin pek çok gazete ve dergi kapatılırken CHP'ye yakın Akis Dergisi'ne dokunulmadı. Aknoz daha sonra DP Milletvekili olmuş Yassıada'da yargılanmıştır. Yargılama esnasında siyasi konular ve basın yasakları konusunda Menderes’ten aldığı talimatlar doğrultusunda hareket ettiği iddialarını

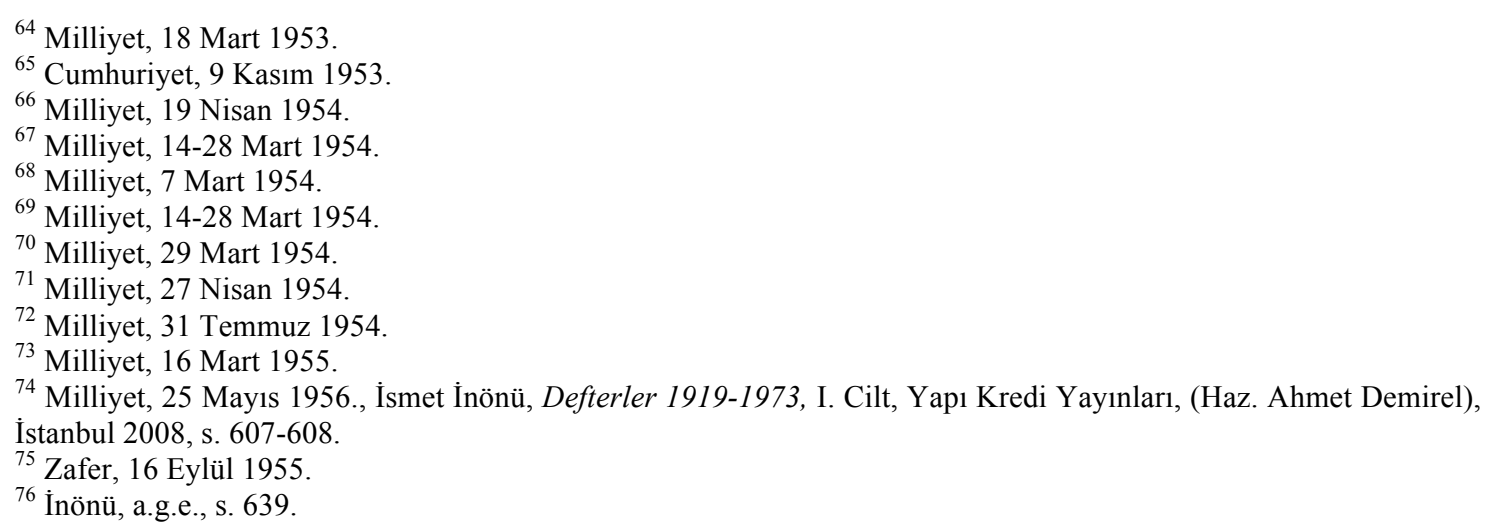


yalanlamıştır. ${ }^{77}$ İnönü İstanbul'da kaldığı süre içinde yakın arkadaşı Gürler ile Taşlık'taki evinde s1k s1k bir araya gelmiş ve zaman zamanda İnönü, Gürler'i ziyaret etmiştir. ${ }^{78}$

Eski Başbakanlardan Şemsettin Günaltay, 22 Temmuz 1957'de CHP İstanbul İl Başkanı olunca il yönetiminde bazı değişiklikler yapmıştır. İl Kadınlar Kolu Başkanlığı'na Gürler'in eşi Emel Gürler yerine Güzide Tanrıyar seçilmiș, Emel Gürler sadece yedek dördüncü üye olarak il yönetimine girebilmiştir. ${ }^{79}$ CHP 1957 seçimlerinde Emel Gürler'i Edirne'den, Şahap Gürler ise İstanbul'dan aday göstermiştir. ${ }^{80} \mathrm{CHP}$ İstanbul il teşkilatında görev almasa da Gürler, CHP Parti Meclisi üyesi olarak 1957 seçimleri için İstanbul'da yürütülen çalışmalara bizzat katılmış ${ }^{81}$, CHP'nin diğer partiler ile yürüttüğü ittifak görüşmelerinde önemli rol oynamıştır. ${ }^{82}$ Emel Gürler de İstanbul Teşkilatındaki görevinden ayrılsa bile eşi ile birlikte İstanbul ve farklı bölgelerde seçim çalışmalarını sürdürmüştür. Örneğin 28 Temmuz 1957 Pazar günü Bayram Sineması'nda CHP Düzce ilçe kongresine Gürler'ler de katılmıştır. ${ }^{83}$

Emel Gürler'in 1957 seçimlerinde aday olduğu Edirne'deki seçim sonuçları DP için oldukça önemliydi. Çünkü DP'nin Edirne Milletvekilleri genelde Menderes'e muhalefetleri ile tanınan, parti grubu içinde muhalefet cephesini oluşturan isimler olmuşlardı. Mükerrem Sarol'un, Menderes'in yakın arkadaşı olarak Edirne'den aday olması bu nedenle önemliydi. Ancak Sarol, seçime az bir süre kala Emel Gürler'in karşısında aday olarak çıkarılınca Edirne'de seçimlerin alınmasının bu şartlar altında zor olduğunu gördü. Edirne DP teşkilatı da Sarol'un bu nedenle adaylıktan çekilmesinden endişe duyuyordu. Sarol, Emel Gürler'in adaylığ1 söz konusu olunca seçim çalışmaları için 11 Ekim 1957'de Edirne'ye gitme kararı almıştır. $^{84}$

Gürler CHP Parti Meclisi üyeliğini aktif bir şekilde sürdürürken 1958'de CHP İstanbul İl yönetiminde idare heyetine girmek için aday olmuştur. 12 Ekim $1958^{\prime}$ 'de yapılan seçimlerde CHP İstanbul İl İdare Heyetine CHP Parti Meclisi'nden İlhami Sancar ve Gürler girmiștir. Böylece Gürler'in Parti Meclisi üyeliği sona ermiştir. ${ }^{85}$ Ancak Gürler CHP'nin Hürriyet Partisi ile ittifak görüşmeleri gibi, kritik konularda aktif bir şekilde çalışmayı sürdürmüştür. ${ }^{86}$ Gürler'in CHP İstanbul İl İdaresi'ne geri dönmesinin temel nedeni parti teskilatının Türkiye'nin kalbi olarak gördükleri bu şehirde güçlü bir yönetimi arzu etmesidir ${ }^{87}$ Çünkü Gürler, CHP İstanbul İl İdaresi’nde yeniden görev aldığında il başkanlığı görevini eski başbakanlardan Şemsettin Günaltay yürütüyordu. Günaltay, İstanbul'da dinamik bir siyaset izlemiyor partililer sık sık onun pasifliğinden şikayet ediyordu. Buna rağmen siyasi kariyeri nedeniyle İstanbul il başkanlığı için en münasip aday Günalatay'dı. Günaltay'ın ekibi CHP Parti Meclisi'nin dört güçlü üyesi, İlhami Sancar, Mebrure Aksoley, Fazıl Şerafeddin Bürge ve Gürler ile takviye edildi. Onların seçim bölgesi İstanbul' daki teşkilatta görev almaları teşkilatta sevinç yaratmıştır. CHP, Gürler'in de içinde yer aldığı yeni ekip ile kısa sürede eksikliklerin

\footnotetext{
77 Metin Toker, Demokrasimizin İsmet Paşalı Yılları: 1944-1973: DP Yokuş Aşağı 1954-1957, Bilgi Yayınevi, Ankara 1991, s. 152.

${ }^{78}$ Toker, DP Yokuş Aşağl 1954-1957, s. 153.

${ }^{79}$ Milliyet, 23 Temmuz 1957.

${ }^{80}$ Milliyet, 30 Eylül 1957., Milliyet, 5 Ekim 1957.

${ }^{81}$ Milliyet, 9 Mayıs 1957.

${ }^{82}$ Milliyet, 17 Ağustos 1957.

${ }^{83}$ Fatih Özçelik, Cumhuriyet Döneminde Düzce (1946-1960), İdeal Kültür Yayınc1lık, İstanbul 2017, s. 196.

${ }^{84}$ Mükerrem Sarol, Bilinmeyen Menderes, Kervan Yayınları, İstanbul 1983, s. 772.

${ }^{85}$ Milliyet, 9-13 Ekim 1958.

${ }^{86}$ Milliyet, 29 Kasim 1958.

${ }^{87}$ Akis, 11 Ekim 1958.
} 
tamamlanacağ ve İstanbul'da önemli başarılar elde edileceğine inanıyordu. ${ }^{88}$ Ancak Gürler 16 Ocak 1959'da yeniden CHP Parti Meclisine seçildi ve İstanbul'daki çalışmalardan uzaklaştı. ${ }^{89}$

Gürler'in yoğun bir şekilde siyaset ile meşgul olduğu günlerde orduda çeşitli darbe yanlısı subaylar çeşitli gruplar oluşturmuş ve bazı subaylar 27 Mayıs 1960'da gerçekleşecek darbe için hazırlıklara başlamıșlardı. Darbenin planlayıcısı olan grup İstanbul'da Harp Okulunda 1955'ten itibaren örgütlenmeye başlamıştır. Ankara'da ise bu süreçte başlıca örgütlenme iki temel gruptan oluşuyordu. Genelkurmay Başkanlığı Protokol Dairesinde görevli bulunan Kurmay Binbaşı Sadi Koçaş ve Albay Kenan Esengin tarafindan oluşturulan gruplar bunların en önemlilerindendi. Ancak Koçaş grubu 9 Subay Hadisesinden sonra dağıldı, yerini başka bir örgüte bıraktı. Binbaşı Osman Koksal, Sezai Okan ve Talat Aydemir grubu ise Ankara'daki ikinci gruptu. İstanbul ve Ankara'daki bu gruplar zaman zaman birleşmek için girişimlerde bulunmuşlar ancak uzun süre bu girişimlerinden netice alamamışlardır. ${ }^{90}$

1957 seçimleri aynı zamanda ordu içindeki darbe yanlısı Koças grubu, Talat Aydemir gurubu gibi bazı gruplar çalışmalarına hız verdiği bir dönemde gerçekleşmiştir. Koçaş grubunun en önemli hedeflerinden biri Koçaş grubuna mensup Binbaşı Baha Vefa Karatay'1 Kara Kuvvetleri Komutanlığı Erkan Şubesi Müdürlüğüne getirerek ordu içindeki atama ve tayinlerde etkili olmaktı. Kurmay Albay Faruk Ateşdağlı, Gürler ile görüşerek onun aracılığı ile Nureddin Aknoz'dan, Karatay'ın Erkan Şubesi Müdürlüğü'ne getirilmesi için yardım istenmesi düşünülmüştür. Koçaş grubu, Gürler'in bu tayinde etkili olacağını düşünüyordu. Çünkü Aknoz, Gürler İkinci Başkan iken kendisinin Genelkurmay Ordu Donatım Daire Başkanlığı'nı yapmış ve aynı zamanda Harp Okulundan dönem arkadaşıydı. Ancak Koçaş, Gürler ile bu konuda temas kurmanın güvenlik ve gizlilik nedeniyle sakıncalı olacağını düşünmüs hatta bu tutumu nedeniyle Ateşdağlı, fazlaca "tedbirli ve hesaplı davranmak" ile suçlanmıştır.

1957 seçimleri öncesi ülkede yükselen siyasi tansiyon darbe yanlısı subayları harekete geçirmiş ve 20 Ekim 1957'de Ankara'da ve 22 Ekim 1957'de İstanbul'da Rami kışlasında yapılan toplantıların ardından darbe yapma kararı alınmıştır. İstanbul'daki toplantıda darbeden önce CHP'nin ileri gelenleri ve İnönü ile temasa geçilmesi kararlaştırılmış böylece onun tecrübelerinden yararlanmak istemişlerdir. Aslında darbe yanlısı subaylar İnönü'nün tavrının darbenin başarısını etkileyeceğini düşünerek onun desteğini almak istemişlerdir. Gürler, 1957 yılında Koçaş ve Ateşdağlı'nın içinde bulunduğu müdahale yanlısı subaylar ile CHP üst yönetimi özellikle İnönü, arasındaki iletişimin sağlanmasında etkili olmuştur. İnönü ile iletişime geçme görevi Kurmay Albay Faruk Ateşdağlı ile Suphi Gürsoytrak'a verilmiştir. Faruk Ateşdağlı, Gürler'in yakın arkadaşı olduğu için önce onunla temasa geçilmiş ve Ateşdağl1, Ankara'da CHP'nin önde gelen isimlerinden Faik Ahmet Barutçu ile Gürler'in araya girmesi ile görüşmüştür. Bu görüşmede Barutçu ve müdahale konusundaki istekleri İnönü’ye ileteceğini belirtmiş, ancak İnönü darbe yanlısı askerler ile görüşmeyeceğini söylemiştir. Hatta Gürler'e "bu örgütten benim haberim olmasın" demiştir. Onun vasitasıyla bu süreçte Faik Ahmet Barutçu ve Şemsettin Günaltay ile görüşülerek destekleri alınmıştır. İnönü seçimlerin CHP tarafından kazanılacağını bu nedenle böyle bir müdahaleye taraftar olmadığını Gürler aracılığıyla darbe yanlısı subaylara iletmiştir. Talat Aydemir'e göre İnönü, darbe yapacak olan

\footnotetext{
${ }^{88}$ Akis, 4 Ekim 1958.

${ }^{89}$ Milliyet, 17 Ocak 1959., Akis, 24 Ocak 1959.

90 Özdă̆, Menderes Döneminde Ordu-Siyaset İlişkileri, s. 78., Hale, a.g.e, s.97-100., Kemal H. Karpat, "The Military arid Politics in Turkey: A Socio-Cultural Analysis of a Revolution," American Historical Review, Vol. 75, No. 6 (Oct., 1970), pp. s.1665.

${ }_{91}$ Özdağ, Menderes Döneminde Ordu-Siyaset İlişkileri, s. 84-87., Sadi Koçaş, Atatürk'ten 12 Mart'a, Anılar, Cilt 1, May Yayınevi, İstanbul 1977, s- 350.
} 
askerlerin iktidarı CHP'ye devretmeyeceğini bildiği için bu girişime destek vermemiştir. ${ }^{92}$ İnönü’de istenilen desteği alamayan subaylar güçlerinin bu tür bir eyleme yeterli olup olmayacağı yönündeki tereddütler nedeniyle bu girişimi ertelemişlerdir. ${ }^{93}$

Gürler, 27 Aralık 1957'de Kurmay Binbaşı Samet Kuşçu'nun ihbarı ortaya çıkan ve Dokuz Subay Olayında gelişmelerden haberdar olan birkaç kişiden birisidir. 27 Mayıs'ta aktif bir şekilde görev yapan Kurmay Binbaşı Ahmet Yıldı, Gürler ile görüşerek tutuklanacak subaylar ve gelişmeler hakkında bilgi vermiştir. ${ }^{94}$ Dokuz subay olayı ile ordu içindeki darbe yanlısı gruplar ilk defa bu kadar açık bir şekilde kamuoyunda deşifre olmuşlardır. Bu olay sonrası yapılan tutuklama ve tasfiyeler, Menderes'te muhalif subayların ordudan atıldığ 1 artık bir darbe tehlikesi bulunmadığı algısını oluşturmuştur. Öte yandan darbe yanlısı subaylar artık daha ihtiyatlı davranmaya başlamışlar, bu süreçte tutuklama ve soruşturma sürecinden etkilenmeyen tek grup Koçaş Grubu olmuştur. Onlar da Gürler ile iletişim halinde olmaya devam etmiş, Koçaş, Şubat 1959'da Orgeneral Cemal Gürsel ile iletişime geçmiş ve 27 Mayıs 1960 'da gerçekleşecek darbenin başında yer alacak üst düzey general de bulunmuştur. ${ }^{95}$

\section{27 Mayls ve Gürler}

Gürler emekliye ayrılmasından sonra fikirlerine yakın bulduğu CHP'de aktif siyasete başlamış, yedi yıl boyunca eşi Emel Gürler ile birlikte DP hükümetine karşı siyaset yapmıştır. Bu süreçte Gürler'in siyasi kariyerindeki en kritik devre 28 Nisan-27 Mayıs arası dönem olmuştur. ${ }^{96} 1957$ 'de hedefine ulaşmayan darbe taraftarı subaylar çalışmalarını sürdürmüşler, Mart 1960'da İstanbul ve Ankara'daki gruplar görüş ayrılıklarına son vererek güç birliği sağlamışlardır. Nisan 1960 'da ise darbe için uygun zemin oluşmuştur. ${ }^{97}$ Darbe yanlısı subayların müdahale için anlaştıkları günlerde iktidar ile muhalefet arasındaki ipleri tamamen koparan bir dizi gelişme yaşanmıştır. Muhalefetin iktidarı görev yapamaz hale getirmek için bir dizi girişim içinde olduğunu ve CHP'nin iktidarı zorla ele geçirmek niyetinde olduğunu iddia eden DP'li Sebati Ataman, Mazlum Kayalar ve Sait Bilgiç, 7 Nisan 1960'da DP meclis grubunda CHP'nin eylemlerine karşı harekete geçilmesi çağrısında bulunmuştur. Zaten Menderes de 31 Mart'ta yaptığı konuşmada bazı olağanüstü önlemler alınacağına dair ipuçları vermişti. ${ }^{98}$ Nisan 1960'1n büyük olaylara gebe olduğu Radyo Gazetesi'nin Zafer Gazetesi'nin 6-7 Nisan 1960 tarihli nüshalarına dayandırdığı haberinden anlaşılıyordu. Habere göre CHP'nin İstanbul teşkilatı tarafından yayınlanan gizli broşürde, teşkilattan, yürütülecek gizli çalışmalara hazırlanması isteniyordu. ${ }^{99}$

Darbeye günler kala İstanbul ve Ankara'da öğrenciler gösteriler yapmaya başlamıştır. Başlangıçta küçük çapta olan bu gösteriler siyasi ortamı oldukça germiştir. Siyasi ortamı geren olaylardan biri İnönü’nün CHP İstanbul İl başkanlığına 20 Nisan 1960'da yaptığı ziyaret üzerine çıkmıştır. Oldukça olaylı geçen bu ziyarette İnönü, CHP’ye katılan binden fazla

\footnotetext{
92 Talat Aydemir, Hatıratım, Yapı Kredi Yayınları, İstanbul 2010, s. 358., Özdağ, Menderes Döneminde OrduSiyaset İlişkileri, s. 84-87., Adnan Çelikoğlu, Bir Darbeci Subayın Anıları 27 Mayıs Öncesi ve Sonrası, (Yayına Hazırlayan: Ergin Konuksever), Yapı Kredi Yayınları, İstanbul, 2010, s. 81-82.

93 Özdağ, Menderes Döneminde Ordu-Siyaset İlişkileri, s. 84-87. Koçaş, a.g.e., s. 350.

94 Özdağ, Menderes Döneminde Ordu-Siyaset Iliş̧kileri, s. 86-87.

${ }^{95}$ Hale, s.97-100. 133.

${ }_{97}^{96}$ Akis, 30 Haziran 1960, s.17-18, 20.

${ }^{97}$ Albayrak, a.g.e., s. 545.

${ }^{98}$ Başgil, a.g.e., s. $115-121$

99 Feroz Ahmad, Bedia Turgay Ahmad, Türkiye'de Çok Partili Politikanın Açıklamalı Kronolojisi: (1945-1971), Bilgi Yayınevi, Ankara 1976, s. 207.
} 
üniversite öğrencisinin üyelik belgelerini imzalayacaktı. İnönü orada fazla kalmamış ancak öğrenciler dağıldıkları esnada polisin sert müdahalesi ile karşı karşıya kalmışlardır. ${ }^{100}$

DP'nin muhalefete karşı olağanüstü önlemler almak üzere hazırlık yürüttüğü bu dönemde İnönü, bir dizi toplantı yaparak cevap vermiştir. Tahkikat Komisyonu'nun görüşmeleri DP grubunda başlamadan hemen önce 16 Nisan 1960'ta İnönü Taşlık'taki evinde Genel Sekreter Kasım Gülek ve 12 emekli General ile buluştuğunda bu emekli generallerin içinde Gürler'de vardır. İnönü bu ziyaret sonrası yaptığı açıklamada "Milletin bünyesinde kuvvetli bir varlıksınız. Milletin gözü kulağı, ihtiyacı olduğu zaman, olmadığı zaman size müteveccihtir........Sizinle yaptığım bu toplantıdan Ankara'ya çok daha canlanmış olarak dönüyorum." demiştir. ${ }^{101} 20$ Nisan 1960 'da günü 28 Nisan olaylarında yaralanacak olan İstanbul Üniversitesi Rektörü Sıddık Sami Onar, eski Genelkurmay Başkanı Abdurrahman Nafiz Gürman, Şahap Gürler, General Kâmil Akman'la Kurmay Albay Cemal Yıldırım İnönü'yü ziyaret etmiştir. Taşlık’taki evde yarımşar saat arayla gerçekleşen bu görüşmelere DP çok sert tepki göstermiştir. Bunun bir ihtilal hazırlı̆̆ı olduğu iddia edilmiştir. Bu ziyaretler darbeden önce yapıldığı için ve İnönü’nün açıklamaları, ordunun İnönü'yü, İnönü’nün orduyu desteklediği şeklinde yorumlanmıştır. ${ }^{102}$

18 Nisan'da DP grubunda 27 Nisan'da da TBMM'de yapılan görüşmelerin ardından geniş yetkilerle donatılmış bir Meclis araştırma komisyonu, yani Tahkikat Komisyonu kurulmuştur. Komisyon şüphelileri sorgulama ve tutuklama yetkisi ile asliye mahkemesi sorgu hakimi gibi görev yapacaktı. Komisyon gerçek ve tüzel kişilerin faaliyetleri ve malî kaynakları hakkında derin incelemelerde bulunabilecek, gerekli gördügü hâllerde basına soruşturma ile ilgili yayın yasağı koyabilecekti. Tahkikat Komisyonu'nun kurulmasına CHP çok sert tepki göstermiştir. Kanun taslağ 1 Genel Kurul'da görüşülürken, İstanbul Hukuk Fakültesi'nden bazı hocaların da desteği ile üniversite öğrencileri protesto gösterisi düzenlemiş ve 27 Mayıs'a giden süreç bu protestolarla başlamıştır. Bu protestolarda hukuk fakültesinden bazı hocaların gazetelerde yaptığı açıklama etkili olmuş ve 27 Nisan öğleden sonra CHP'ye bağlı öğrenci grupları 28 Nisan 1960'ta gerçekleştirecekleri büyük gösteri için hazırlık yapmaya başlamıştır. 28 Nisan'da çıkan ve Turan Emeksiz'in polis tarafından öldürüldüğü olaylar, Ali Fuat Başgil'e göre CHP tarafından organize edilmiştir. Emeksiz'in öldürülmesinin ardından büyüyen olaylara müdahale konusunda polis yetersiz kalmıș üniversite avlusuna piyade birlikleri girmiștir. Piyade birlikleri subaylarla birlikte öğrencilerin üzerine yürürken bir anda öğrenciler "Yaşasın ordu! Yaşasın kahraman Türk askeri!" diye bağırmaya başlamış kısa süre sonra askerler durmuş subaylar, askerler ve öğrenciler birbirlerini kucaklamışlardır. Böylece öğrenci olaylarına askerde katılmıştır. ${ }^{103}$ Yakup Kadri Karaosmanoğlu'na göre ise bu olaylar CHP gençlik teşkilatınca organize edilmiştir. Olayların ardından İstanbul ve Ankara'da sıkıyönetim ilân edilmiş İstanbul Sıkıyönetim Komutanlığı'na General Fahri Özdilek, Ankara sıkıyönetim komutanlığına da General Namık Argüç getirilmiştir. İstanbul ve Ankara'da her türlü toplantı sıkıyönetim tarafından yasaklanmış üniversiteler bir ay süreyle kapatılmıştır. ${ }^{104} 28$ Nisan olayları esnasında Gürler de İstanbul'da gözaltına alınmış, hatta o dönemde İstanbul'un 1 Numaralı S1k1 Yönetim Hakimi Binbaşı Abdullah Ayagün Yassıada'da verdiği ifadede

\footnotetext{
${ }^{100}$ Ahmad, a.g.e., s. 206. Metin Toker, Demokrasimizin Ismet Paşalı Yılları: 1944-1973 : Demokrasiden Darbeye: 1957-1960, Bilgi Yayınevi, Ankara 1991, s. 302-303.

${ }^{101}$ Milliyet, 17 Nisan 1960., Ahmad, a.g.e., s. 208.

${ }^{102}$ Ahmad, a.g.e., s. 206. Toker, Demokrasiden Darbeye: 1957-1960, s. 302-303., Albayrak, a.g.e., s. 545.

${ }^{103}$ Başgil, a.g.e., s. 115-121

${ }^{104}$ Ahmad, a.g.e., s. 209.
} 
Gürler'in ifadesini alırken kendisine "ben biliyorum siz yukarıdan emir almışsınız, beni tevkif edeceksiniz" demiştir. Ancak Ayagün kendisini tutuklamamıştır. ${ }^{105}$

Tahkikat komisyonu görüşmeleri esnasında iktidar muhalefeti açık bir şekilde ihtilâlcilikle suçlamış İnönü ise buna verdiği cevapta "ihtilâlin kendileri ile ilişkisi olmayanlar tarafından yapılacağını" söylemiștir. Darbe açık bir şekilde TBMM'de konuşulmasına rağmen Menderes, ordu içinden kendisine yönelik bir eylem halen beklememektedir. ${ }^{106}$ Ancak 28 Nisan 1960 'da olağanüstü toplantı yapan CHP parti meclisi teşkilatına yönelik yayınladığ 1 bildiride hukuk devleti prensiplerini çiğneyen DP iktidarına karşı mücadele etme kararı alındığını duyurmuştur. ${ }^{107}$

28 Nisan'daki öğrenci olaylarının ardından darbeye doğru giden süreç hızlanmıştır. Bu dönemde CHP İstanbul İl Başkanı Günaltay’dır. Ancak Günaltay, 28 Nisan-27 Mayıs 1960 tarihleri arasında öğrenci olayları zirvedeyken evinden çıkmamaya özen göstermiştir. Bu süreçte il başkanlığını fiili olarak Gürler üstlenmiştir. Gürler darbeye giden süreçte İstanbul'daki öğrenci olayları ve gençlerin faaliyetlerine CHP adına hep destek olmuştur. CHP İstanbul il teşkilatının gençlik kolları kurmayı düşündüğü bir dönemde İstanbul'da öğrenci olayları hız kazanmıştır. Bunun üzerine gençlik teşkilatı kurma işleri bu süreçte askıya alınmış ve CHP'li gençler İstanbul'daki eylemlerin çekirdeğini oluşturmuştur. Kurulması planlanan gençlik teşkilatı Akis dergisine göre Tahkikat komisyonunun kurulma kararının DP tarafından alınmasının ardından 18 Nisan 1960'dan sonra "yeraltı faaliyetine" başlamıştır. Örneğin İnönü'nün TBMM'de ihtilalin meşruluğu ile ilgili konuşmasına yayın yasağı konulmuş, bu konuşma Ulus gazetesinde yayınlanmış ancak hemen gazete toplatılmıştır. İnönü'nün konuşması İstanbul il teşkilatı gençleri tarafından teksire alınarak dağıtımı yapılmıştır. Akis'e göre bu çalışma ile darbeye kadar giden süreçteki gençlik hareketinin temeli atılmıştır. Ardından 18 Nisan 1960'da CHP İstanbul il gençlik komitesi ikinci büyük eylemini yaparak “Atatürk'ün Gençliğe Beyannamesi” ni 50 bin nüsha olarak hazırlamış 23 Nisan 1960'da dağıtmıştır. CHP İstanbul İl teşkilatı gençleri, Tahkikat Komisyonu'nun kurulmasının ardından fiili eylemlerini artırmıştır. Gençlik Kollarının faal bir elemanı olan Nuri Yazıcı, Hukuk Fakültesi'nde mikrofonun başına geçmiş ve gençleri hürriyet mücadelesine davet etmiştir. İstanbul'da başlayan eylemler Ankara'daki üniversitelere ve ülke genelinde liselere kadar yayılmıştır. Bu süreçte İnönü' nün demeçleri, hükümet karşıtı bildiriler, gizli toplantılar yeni eylem planları hazırlanırken CHP İstanbul gençliğinin en büyük destekçilerinden biri Gürler olmuştur. ${ }^{108}$

Herkesin DP'nin hışmına uğramamak için CHP il başkanlığına uğramadığı bir dönemde Gürler, hemen hemen her gün partiye gelmiş, İstanbul Sıkıyönetim Komutanlığı ile dönem dönem karşı karşıya gelmekten çekinmemiştir. Bu olaylardan biri 19 Mayıs münasebetiyle CHP İstanbul İl Teşkilatı'nın Taksim Atatürk Anıtına çelenk koymayı planlamasıyla çıkmıştır. Bu durumdan haberdar olan polis, il başkanlığında görev yapan hanım memuru gözaltına alarak çelenklerin kim tarafından sipariş verildiğini sormuş, o da Gürler'in ismini vermiştir. Gürler gelen polislere teslim olmayacağını söylemiş, daha önce yanında çalışan eski askeri olan İstanbul Sıkıönetim Komutanı Fahri Özdilek'e 19 Mayıs 1960'da "Böyle tarihi bir günde kendi kurduğu partisinin, Cumhuriyet anıtına çelenk koyma teşebbüsünün suç telakki edilmekte olduğunu tebligatınızdan öğrenmekle hakikaten üzülmüş

\footnotetext{
${ }^{105}$ Milliyet, 16 Nisan 1961.

${ }_{106}^{106}$ Albayrak, a.g.e., s. 545.

107 Taner Demirel, Türkiye'nin Uzun On Y1lı Demokrat Parti İktidarı ve 27 Mayıs Darbesi, İstanbul Bilgi Üniversitesi Yayınları, İstanbul, 2011, s. 330.

108 Akis, 30 Haziran 1960, s.17-18, 20., Demirel, a.g.e., s. 332-335., Hakkı Uyar, Demokrat Parti İktidarında CHP 1950-1960, Doğan Kitap, İstanbul, 2017, s. 342.
} 
bulunuyorum. Atatürk'ün izinde olması lazım gelen ve bugün yaşayan neslin ona yalnız bir çelenk koymakla yetinmesi dahi azdır. Ona lâyık olmadığımızdan dolayı bize ancak heykelinin ayaklarına kapanarak af talep etmek düşüyor kanaatindeyim. Bu yolda her mesuliyeti seve seve kabul ediyorum." yazan bir telgraf yollamıştır. Özdilek eski komutanını bir şeyler yapmak zorunda olduğu için gözaltına alarak mahkemeye sevk etmiştir. 26 Mayıs 1960'da yani darbeden bir gün önce Gürler, CHP İstanbul il başkanlığının fiili yöneticisi olarak askeri mahkemeye çıkmış, saat 10'da gerçekleşen duruşmanın ardından serbest bırakılmıştır. Gürler, serbest bırakılmasının ardından hemen Harbiye'deki öğrencileri ziyaret etmiş ve onlara "pek yakında" kurtulacakları müjdesini vermiştir. ${ }^{109}$

\section{27 Mayıs Sonrası Gürler}

Gürler, 27 Mayıs 1960’ta meydana gelen darbenin ardından, önce Nizamettin Nazif Tepedelenlioğlu tarafından kurulan Hür Nizam adlı haftalık siyasi gazetede yazacağ 1 "kendi fikir ufkunun bir numaralı şeref imzası" olarak duyurulmuştur. ${ }^{110}$ Ardından CHP'ye yakın Akis dergisinin 30 Haziran 1960'daki sayısına tam boy kapak olmuştur. CHP İstanbul İl Başkanı Günaltay, 27 Mayıs 1960 sonrası görevi resmen bırakmıştır. Tahkikat Komisyonu'nun kurulmasının ardından İstanbul'da artan öğrenci olaylarında ön safta yer alan, Şemsettin Günaltay'ın İstanbul İl Başkanlığı'nda gören dahi olmadığı bu kritik süreçte bütün yük Gürler tarafindan üstlenilmiştir. Akis dergisine göre Gürler'in bu göreve atanması ve İstanbul'da CHP'lilerin Gürler'i istemesinde Gürler'in İstanbul'da öğrenci olaylarının arttığı günlerde CHP'nin İstanbul il başkanlığına her gün gelmesi bazen sadece tek başına burada görev yapmasıydı. Bu tavrı ile partililerine örnek olarak onların cesaretinin artmasını sağlamıştır. Cesur bir politikacının böyle kritik bir dönemde nasıl davranması gerektiğine dair önemli bir örnek olmuştu. ${ }^{111} \mathrm{Bu}$ kritik dönemde ve siyasi hayatındaki başarılar nedeniyle Gürler'in CHP İstanbul İl başkanlığına atanması için il teşkilatı CHP Genel merkezine başvurmuştur. Böylece CHP'nin güçlü bir şekilde seçimlere hazırlanması düşünülüyordu. ${ }^{112}$ Gürler, Şemsettin Günaltay'ın istifasının ardından İnönü'nün de desteği ile 20 Temmuz 1960'da CHP İstanbul İl Başkanı olmuştur. ${ }^{113}$

Gürler, darbe sonrası Milli Birlik Komitesi ile yakın irtibat halinde olmuş hatta MBK Üyesi Cemal Madanoğlu'na CHP'nin iktidara gelmesi durumunda kendisini genelkurmay başkanı yapacakları vaadinde bulunmuştur. ${ }^{114} 27$ Mayıs'ın ardından Genelkurmay Başkanı olan Cemal Gürsel ile de yakın iletişim halinde olmaya devam etmiştir. Gürsel'in Kara Kuvvetleri Komutanlığı esnasında orduda DP karşıtı subayları korumasını takdirle karşılamış onunla ilgili Cihad Baban'a "Cemal Paşa orduda mertliği, arkadaşlarına karşı gösterdiği yakınlık ile tanınmıştır. Disiplin adamıdır, elbet iktidara saygı gösterir, fakat iktidar millete ve orduya saygı göstermezse, o da boyun eğmez..." demiştir. ${ }^{115}$

Gürler 27 Mayıs'ın ardından İnönü ile yakın bir şekilde çalışmayı sürdürmüştür. CHP İstanbul İl Başkanlığı süresince CHP'yi iktidara taşımak için yoğun bir şekilde çalışmıştır. Bu çalışmalar İnönü'nün takdirini kazanmıştır. CHP çevreleri Gürler'in başarılı teşkilatçılığını yeniden ispat ettiğini düşünüyordu. ${ }^{116}$ Gürler, 27 Mayıs'ın ardından 10 Temmuz'da İstanbul'a

\footnotetext{
${ }^{109}$ Akis, 30 Haziran 1960, s.17-18, 20.

${ }^{110}$ Milliyet, 2 Temmuz 1960.

111 Akis, 30 Haziran 1960, s.17-18, 20., Akis, 16 Haziran 1960, s. 27.

${ }_{112}$ Akis, 30 Haziran 1960, s.17-18, 20.

${ }^{113}$ Milliyet, 21 Temmuz 1960.

${ }^{114}$ Muammer Taylak, 27 Mayıs ve Türkeş, Ayyıldız Matbaası, Ankara 1977, s. 117-118.

${ }^{115}$ Cihad Baba, Politika Galerisi Bir Devrin Hükümranları, Timaş Yayınları, İstanbul 2009, s. 250.

${ }^{116}$ Akis, 12 Eylül 1960.
} 
dinlenmek için gelen İnönü’yü Bostancı İstasyonu'nda karşılamış ${ }^{117}$ İstanbul İl Başkanı olmasının ardından 2 Ağustos 1960'da İnönü'yü Heybeli Adada ziyaret etmiş, İnönü bu ziyarette Gürler'den Milli Birlik Komitesi Hükümetine yardımcı olmasını istemiştir. ${ }^{118}$

Gürler bir yandan da Hür Nizam adlı dergide yazılarına devam etmiş, denetleme amacıyla gittiği Kore ile ilgili olarak "Yarısı kızıl, yarısı beyaz bir Çin köyünden, bir İngiliz mangası arasında nasıl geçtim?" başlıklı bir makalesi yayınlanmıştır. ${ }^{119}$ Yassıada yargılamaları başlayınca adaya en rahat gidip gelebilen, dolayısıyla mahkemeleri yakından takip eden isimdir. ${ }^{120}$ İnönü için düzenlenen doğum günü partisinde yine İnönü'nün en yakınındaki Gürler olmuştur. ${ }^{121}$ Gürler, 21 Aralık 1960'ta darbe sonrası oluşturulan Temsilciler Meclisinde CHP'nin İstanbul temsilcisi olarak seçilmiştir. ${ }^{122}$ Temsilciler Meclisinde ise Gürler, Milli Savunma Komisyonu'nda Başkan olarak görev almıştır. ${ }^{123}$ Gürler bir süre sonra siyaseti bırakarak Birleşmiş Milletler Filistin Mültecilerine Yardım ve Bayındırlık Ofisi'nde (UNRWA) ${ }^{124}$ Türkiye delegesi olarak on iki bin lira maaş ile Beyrut'a görevlendirilmiştir. ${ }^{125}$ Bunun üzerine Kurucu Meclis üyesi Gürler, hükümet tarafından yurt dışında görev verildiği için üyelikten 7 Nisan 1961'de istifa etmiştir. ${ }^{126}$ Eşi Emel Gürler Eylül 1961'de CHP'den İstanbul Milletvekili adayı olmuştur. ${ }^{127}$

Gürler, Beyrut elçliği aracılığı ile Ağustos 1961'de, Milli Savunma Bakanlığı'na başvurmuş ve 10 Eylül 1952 'de DP hükümeti tarafından haksız bir şekilde resen emekliye sevkediliğini bu kararın iptali istemiştir. Bakanlık Gürler'in dilekçesini bu durumun idari işlemle düzeltilemeyeceğini belirterek meclise sevk etmiştir. Bunun üzerine komisyon emekliye sevk işleminin hukuksuz olduğunu bu nedenle iptaline karar vermiştir. ${ }^{128}$ TBMM Karma Dilekçe Komisyonu 26 Nisan 1963'te yaptığı toplantıda DP döneminde emekliye sevk edilen Orgeneral Gürler'in ve 6 yüksek rütbeli subayın emeklilik işlemini iptal etmiştir. TBMM'de alınan karar doğrultusunda Gürler'in emeklilik işlemleri durdurularak orgeneral rütbesi ile tekrar emekliye sevk ediliștir. ${ }^{129}$

Harp, liyakat ve İstiklal Madalyalarının yanı sıra Almanya ve Avusturya askeri liyakat nişanı sahibi üç çocuk babası Gürler ${ }^{130} 8$ Ekim 1966'da kalp krizi geçirerek Gülhane Askeri Tıp Akademisi'nde Ankara'da vefat etmiştir. Cenazesi Ankara'dan ayrılmadan önce Genelkurmay önünde tören düzenlenmiştir. Gürler, öldüğünde Birleşmiş Milletler Filistin Mültecilerine Yardım ve Bayındırlık Ofisi'nde Türkiye temsilciliği görevini halen yürütüyordu. Kurtuluş Savaşı'na katılan Genelkurmay İkinci Başkanlığı görevini üslenen Gürler'in cenazesi askeri uçakla İstanbul'a getirilmiş ve 10 Ekim 1966'da Fatih Camii'nde k1lınan namazın ardından askeri törenle Edirne Kapı Şehitliği'ne defin edilmiştir. ${ }^{131}$

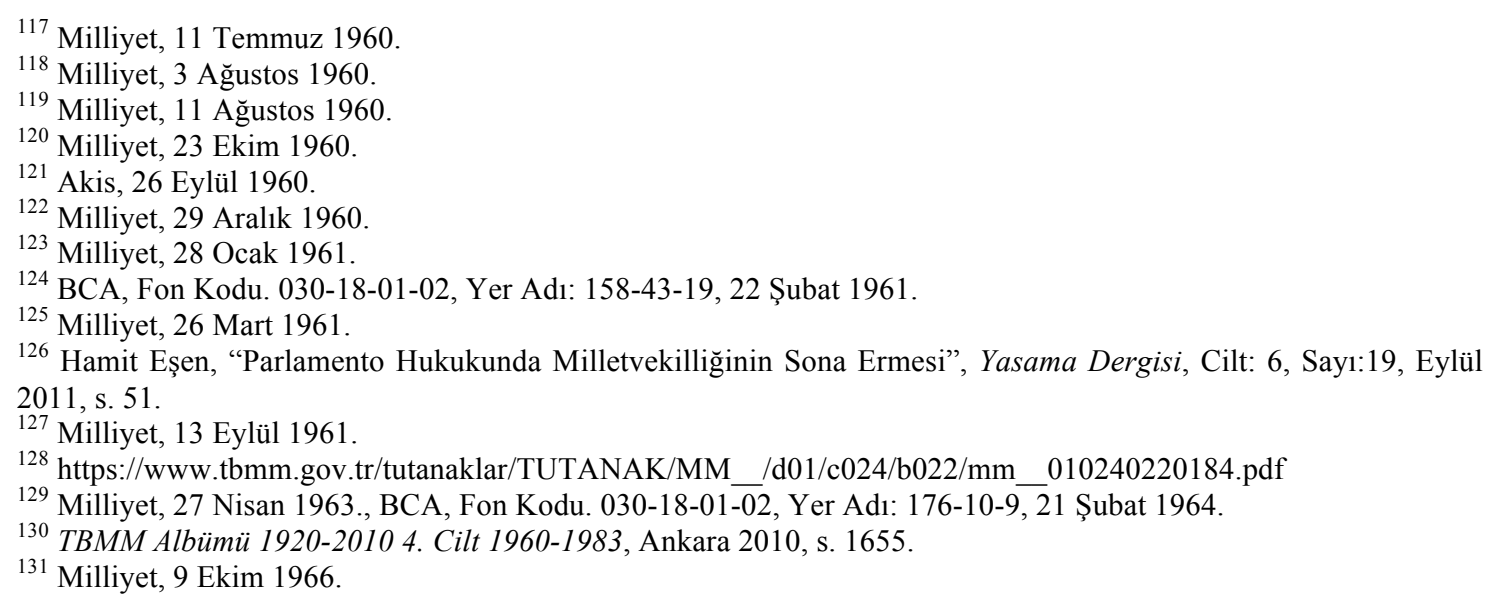


Sопuç

II. Meşrutiyet'ten itibaren ordu ve siyaset arasındaki ilişki Türkiye'de en önemli gündem maddelerinden biri olmuştur. Atatürk döneminde ordunun siyaset üzerindeki etkisi sınırlandırılmış ancak onun ölümünün ardından ordu içinde siyasete yönelim yeniden artmıştır. II. Dünya Savaşı'nın ardından artan dış tehdidin paralelinde Türkiye'de ordu yeniden başlıca gündem maddesi olmuştur. Savaşın ardından Batılı ülkelerle kurulan yakın ilişkinin en önemli yönlerinden birinin ordu olması, tek parti döneminin sona ermesi ile başlayan askeri ve sivil bürokrasiye yönelik eleştiriler, orduyu yeniden siyasetin içine çekmiştir. Ordu içindeki bazı subaylar Türkiye'nin ekonomik ve siyasal sisteminin, askeri yapısının köklü bir değişim geçirdiği bu süreçte söz sahibi olmak istemiştir. Daha DP iktidara gelmeden ordu içinde bazı gruplar oluşmuş ve bunlar siyasete müdahale etmek istemişlerdir. DP iktidara geldiğinde Türk ordusu içinde DP yanlısı ve CHP taraftarı subaylar arasında ayrışma çoktan oluşmuştu.

Gürler gerek asker öğrenci gerek general olarak ordunun her kademesinde görev yapmış bir isimdi. Ordunun durumunu ve içerde yaşanan bölünmeleri yakından bilen Gürler, TSK'nın Batılı müttefiklerin yardımı ile modernleşmesi sürecinde CHP ve DP döneminde görev yaptı. Biraz da bu nedenle DP'nin iktidara gelir gelmez 6 Haziran'da gerçekleştirdiği büyük tasfiyenin dışında tutuldu. DP'nin Genelkurmay İkinci Başkanlığı görevine Yamut'un isteğine rağmen Gürler'i getirmemesinde ise onunla ilgili tereddütler etkili olmuştur. $\mathrm{Bu}$ dönemde Gürler saha görevleri esnasında DP iktidarının icraatlarını yakından gözlemleme imkanı bulmuş̧tur. Öte yandan DP'yi destekleyen pek çok generalin DP'den uzaklaştığı günlerde oda, DP iktidarına karşı olumsuz tavır içine girmiştir. DP döneminde Gürler, Batı güvenlik sistemi içinde Türk ordusunun yerinin belirlenmesinde aktif görev almıştır. Yabancı askeri heyetler ile yapılan görüşmelerde ve NATO'ya üyelik sürecinde ordu adına masada oturan birkaç generalden biriydi. Bu süreçte izlediği Batı ile işbirliğine açık tutum ile İngiltere ve ABD'nin takdirini kazandı. Hatta $A B D$ onun Genelkurmay İkinci Başkanı olarak atanmasında etkili oldu. Gürler'in Batılı ülkeler nezdinde değeri artar, ordu içindeki konumu güçlenirken, muhalif tavrı ve ordu üzerindeki etkisinin artması nedeniyle DP iktidarının hedefi haline gelmiştir. Gürler, 25 Temmuz 1952'de ani bir kararla emekliye sevk edilmiştir. Gürler'in görevden alınmasından sadece birkaç gün önce Orta Doğu'nun 20. Yüzyıl boyunca sık sık şahit olduğu darbelerin belki de en önemlisi ve ses getireni gerçekleşmiş, Hür Subaylar adlı bir grup asker Mısır'da darbe yaparak yönetimi ele geçirmiştir. Gürler'in görevden alınmasında bu darbenin DP üzerinde yarattığı tedirginlik etkili olmuştur. Uzun süredir Gürler'e şüphe ile bakan DP iktidarı tıpk1 6 Haziran 1950'de olduğu gibi zamanında müdahale etmezse, Gürler öncülüğünde bir grup askerin kendisine karşı harekete geçebileceğini düşündüğü için böyle bir karar almıştır. Gürler'in eşi Emel Gürler'in CHP saflarında siyaset yapması görevden alınmasında etkili olan faktörlerden sadece biridir. Bu görevden alma Türk ordusu ile Orta Doğu güvenliği ve Sovyetler Birliği'nin yayılmacı faaliyetlerini önlemek için yoğun işbirliği yürüten ABD ve İngiltere'de rahatsılılı yaratmıştır. Çünkü onlara göre Gürler, ordu içinde Batı ittifakı ile işbirliğine önem veren yetenekli generallerden biriydi.

Gürler ordundan ayrılmasının ardından CHP saflarında siyaset yapmaya başlamış, milletvekili adayı olmuş, parti içinde üst düzey görevlerde bulunmuştur. Ancak onu CHP açısından asıl önemli kılan yönü, CHP ile ordu arasındaki güçlü bağlantılardan biri olmasıydı. Ordu içinde sevilen ve saygın bir general olan Gürler, 1957'den sonra ordu içinde DP'ye karş1 oluşan gruplar ile temas halinde oldu. 27 Mayıs'a giden süreçte DP'nin sonlandırmakta aciz kaldığı öğrenci gösterilerinin İstanbul planlamasında aktif bir şekilde görev yaptı. 27 Mayıs sonrası CHP ile Milli Birlik Komitesi arasındaki stratejik bağlantılardan biri olmaya devam etti. Kurucu Meclis'te İstanbul Temsilcisi olarak görev yaptı. Son görevi ise pasif bir şekilde

\section{History Studies}


varlığını sürdüren Birleşmiş Milletler Filistin Mültecilerine Yardım ve Bayındırlık Ofisi’nde Türkiye temsilciliği oldu.

\section{Kaynakça}

\section{Arşiv Belgeleri}

BCA, Fon Kodu. 030-18-01-02, Yer Adı: 158-43-19, 22 Şubat 1961.

BCA, Fon Kodu. 030-18-01-02, Yer Adı: 176-10-9, 21 Şubat 1964.

BCA, Fon Kodu. 490-01-00-00, Yer Ad1: 360-1242-3, 18 Mart 1950.

BCA, Fon Kodu. 030-01-01-00, Yer Adı: 56-345-5, 30 Aralık 1950.

N.A., (The National Archives) FO, (Foreing Office) 195/2686/10719G, 31 Temmuz 1952.

N.A., FO, 195/2686/10719G/10719/81/52G, 29 Temmuz 1952.

N.A., FO, 195/2686/W10719/8/52G, 28 Temmuz 1952.

\section{Gazete ve Dergiler}

Akis

Akşam

Ayın Tarihi

Cumhuriyet

Milliyet

Yeni İstanbul

Yeni Sabah

Zafer

\section{Kitap ve Makaleler}

AHMAD, Feroz, AHMAD, Bedia Turgay, Türkiye'de Çok Partili Politikanın Açıklamalı Kronolojisi: (1945-1971), Bilgi Yayınevi, Ankara 1976, s. 207.

ALBAYRAK, Mustafa, Türk Siyasi Tarihinde Demokrat Parti 1946-1960, Phoenix Yayınları, Ankara 2004.

ARCAYÜREK, Cüneyt, Yeni İktidar Yeni Dönem 1951-1954, Bilgi Yayınevi Ankara 1984, s.89.

ATLI, Cengiz, "1950 Yılı Kars Milletvekilliği ve Belediye Seçimleri”, Ankara Üniversitesi Türk İnkılap Tarihi Enstitüsü Atatürk Yolu Dergisi, Say1: 51, Bahar:2013, s. 522-526.,

AYDEMIR, Şevket Süreyya, İhtilalin Mantığ1 ve 27 Mayıs İhtilali, Remzi Kitapevi, İstanbul 1973.

AYDEMIR, Şevket Süreyya, İkinci Adam, III. Cilt, Remzi Kitapevi, İstanbul 1968.

AYDEMIR, Talat, Hatıratım, Yapı Kredi Yayınları, İstanbul 2010.

BABAN, Cihad, Politika Galerisi Bir Devrin Hükümranları, Timaş Yayınları, İstanbul 2009.

BASGIL, Ali Fuat, 27 Mayıs İhtilali ve Sebepleri Görüp Yaşadıklarım, Yağmur Yayınevi, İstanbul 2006.

ÇELIKOGLU, Adnan, Bir Darbeci Subayın Anıları 27 Mayıs Öncesi ve Sonrası, (Yayına Hazırlayan: Ergin Konuksever), Yapı Kredi Yayınları, İstanbul, 2010.

ÇOLAK, Filiz, "Demokrat Parti Döneminde TBMM'deki Kadın Milletvekilleri ve Meclisteki Faaliyetler (1950-1960)", Tarih Okulu Dergisi (TOD) Journal of History School (JOHS), Aralık 2017, Y11 10, Sayı XXXII, ss. 115-158s.

DEMIREL, Taner, Türkiye'nin Uzun On Y1lı Demokrat Parti İktidarı ve 27 Mayıs Darbesi, İstanbul Bilgi Üniversitesi Yayınları, İstanbul, 2011.

EROGUL, Cem, Demokrat Parti Tarihi ve İdeolojisi, İmge Yayınevi, Ankara 2003. 
ESEN, Hamit, "Parlamento Hukukunda Milletvekilliğinin Sona Ermesi”, Yasama Dergisi, Cilt: 6, Sayı:19, Eylül 2011.

Foreign Relations of the United States (FRUS), 1952-19541, (Washington, 1969), Vol. VIII, https://hstory.state.gov/hstorcaldocuments/frus1952-54v08/d467

GÜN, Taner, “Atatürk'ün Donanma Gemileri ile Yaptığı Geziler”, Dokuz Eylül Üniversitesi, Atatürk İlkeleri ve İnkılap Tarihi Enstitüsü, İzmir 2007. (Yayımlanmamış Yüksek Lisans Tezi)

GÜVEN, Cüneyt, "Sebep ve Sonuçlarıyla Kore Savaşı ve Türkiye", Pamukkale Üniversitesi Sosyal Bilimler Enstitüsü, Denizli, 2007, s. 181-183. (Yayımlanmamış Yüksek Lisans Tezi)

HALE, William, Türkiye'de Ordu ve Siyaset: 1789'dan Günümüze (Çev: Ahmet Fethi), Hil Yayınları, İstanbul 1996.

https://www.tbmm.gov.tr/tutanaklar/TUTANAK/MM_/d01/c024/b022/mm_010240220184. pdf

İNÖNÜ, İsmet, Defterler 1919-1973, I. Cilt, Yapı Kredi Yayınları, (Haz. Ahmet Demirel), İstanbul 2008.

KARPAT, Kemal H., "The Military arid Politics in Turkey: A Socio-Cultural Analysis of a Revolution," American Historical Review, Vol. 75, No. 6 (Oct., 1970).

KAYALI, Kurtuluş, Ordu ve Siyaset 27 Mayıs-12 Mart, İletişim Yayınları, İstanbul 1994.

KOÇAS, Sadi, Atatürk'ten 12 Mart'a, Anılar, Cilt 1, May Yayınevi, İstanbul 1977.

MÜTERCIMLER, Erol, ÖKE, Mim Kemal, Düşler ve Entrikalar Demokrat Parti Dönemi Türk Dış Politikası, Alfa Yayıncılık, İstanbul 2004.

ÖZÇELIK, Fatih, Cumhuriyet Döneminde Düzce (1946-1960), İdeal Kültür Yayınc1lı,, İstanbul 2017, s. 196.

ÖZDAG, Ümit, Menderes Döneminde Ordu-Siyaset İlişkiler ve 27 Mayıs İhtilali, Boyut Yayıncılık, İstanbul 1997.

ÖZDAG, Ümit, Ordu-Siyaset İlişkisi: Atatürk-İnönü Dönemleri, Gündoğan Yayınları, Ankara 1991.

ÖZTÜRK, O. Metin, Ordu ve Politika, Gündoğan Yayınları, Ankara 2000.

SAROL, Mükerrem, Bilinmeyen Menderes, Kervan Yayınları, İstanbul 1983.

SOYSAL, İsmail, Soğuk Savaş Dönemi ve Türkiye Olaylar Kronolojisi: 1945-1975, İsis Yayımcılık, İstanbul 1997.

TAYLAK, Muammer, 27 Mayıs ve Türkeş, Ayyıldız Matbaası, Ankara 1977.

TBMM Albümü 1920-2010 4. Cilt 1960-1983, Ankara 2010.

TBMM Zabıt Ceridesi, Devre: XI, Cilt: 9, İçtima: 2, 8 Haziran 1959.

TOKER, Metin Demokrasimizin İsmet Paşalı Yılları: 1944-1973: DP Yokuş Aşağı 1954-1957, Bilgi Yayınevi, Ankara 1991.

TOKER, Metin, Demokrasimizin İsmet Paşalı Yılları: 1944-1973: Demokrasiden Darbeye: 1957-1960, Bilgi Yayınevi, Ankara 1991, s. 302-303.

TÜNAY, Bekir, Menderes Devri Anıları Gördüklerim, Duyduklarım, Bildiklerim, Nilüfer Matbaacılık, İstanbul (Tarih yok)

UYAR, Hakk1, Demokrat Parti İktidarında CHP 1950-1960, Doğan Kitap, İstanbul, 2017.

YALMAN, Ahmet Emin, Yakın Tarihte Görüp Geçirdiklerim 1922-1971 C. II, Pera Yayıncılık, İstanbul 1997, s. 1531.

YETKIN, Çetin, Türkiye'de Askeri Darbeler ve Amerika, 27 Mayıs, 12 Mart ve 12 Eylül'de ABD'nin Yeri, Ümit Yayıncılık, Ankara 1995. 